DOI https://doi.org/10.30525/978-9934-588-86-0.12

\title{
MODELING OF SEA TRANSPORT INFRASTRUCTURE OBJECTS
}

\author{
Lapkina I. O., Malaksiano M. O.
}

\section{INTRODUCTION}

The efficiency of modern logistics hubs largely depends on the coherence and coordination of a large number of processes running in parallel, as well as the management of available resources. Characteristics of cargo flow, specifics of navigation, weather conditions, specifics of operation of associated modes of transport and a number of other factors have a significant impact on the performance indicators of port terminals. Herewith, the tasks of organizing the work of terminals are often complicated because the intensity and structure of cargo flows in the future may be subject to significant variations.

Improving the efficiency of transport systems requires the introduction of new technologies and the use of advanced planning methods. At present, integrated electronic information tools are being actively developed and used to improve the efficiency of transport systems through better coordination of cargo transportation and optimization of the use of valuable resources. Efficient use of equipment is a key factor of successful operation of sea terminals. Therefore, the issues of justifying the optimum terms of equipment renewal are of great practical interest. The advisability of equipment replacement arises for several reasons. First, this is due to wear and tear. Wear and tear can be caused by abrasion of parts, fatigue of materials, oxidation and other reasons. The increase in wear and tear is manifested in the increase in the number of breakdowns and growth of operating costs of equipment. Secondly, the advisability of equipment replacement is associated with obsolescence, caused by the emergence of more efficient or cheaper analogs of equipment in the market. In many cases, the advisability of equipment renewal is determined not by one type of wear, but by the combined effect of wear and tear and obsolescence on equipment.

Planning of terms of replacement of aging equipment with new equipment often should take into account the impact of various random factors. Equipment performance depends on external factors such as equipment utilization rate, the nature of the work performed, weather conditions, etc., which are subject to accidental changes. Even for similar machines used under identical conditions, the dynamics of wear and tear can be significantly different. And this should be taken into account when planning the terms of equipment renewal. 
Currently, many enterprises in Ukraine, including seaports, need upgrading of equipment. This causes a significant practical interest in the development of scientifically based methods for determining the optimum terms of switching to a new type of equipment. The relevance of work in this direction is also explained by the need to develop control methods aimed at reducing the degree of dispersion of possible values of equipment performance indicators.

\section{DESIGN AND OPTIMIZATION OF SEA TRANSPORT INFRASTRUCTURE USING SIMULATION MODELING METHODS}

A number of scientific works are devoted to research the optimal organization of the work of sea terminals. The paper by J. Rodrigue and T. Notteboom ${ }^{1}$ discusses the way logistics service providers use the terminals in their supply chains. It addresses how the development of seaport and inland terminals affects supply chains by increasingly confronting market players with operational considerations such as imposing berthing windows, dwell time charges, truck slots, all this to increase throughput, optimize terminal capacity and make the best use of available land. The article by J. Felício, V. Caldeirinha and A. Dionísio ${ }^{2}$ examines port and container terminal characteristics such as location, physical infrastructure and service, and assesses how they affect performance.

Influence of a choice of structure of park of the equipment and management of its updating on indicators of efficiency of functioning of the sea terminal has been studied by M. Postan, L. Kushnir and N. Malaksiano. In article "A method of determination of port terminal capacity under irregular cargo delivery and pickup" 3 estimations of fluctuations of operational indexes and stability of economic indexes of equipment working under unstable load have been received. Assuming that the flow of incoming cargoes described by a complex Poisson zero-drift model, a system of integral differential equations with corresponding boundary conditions was derived and studied in order to find the limit of joint distribution of the number of docked vessels and the number of cargoes in the warehouse. In paper "On the stability of economic

${ }^{1}$ Felício J. A., Caldeirinha V., Dionísio A. (2015) The effect of port and container terminal characteristics on terminal performance. Maritime Economics \& Logistics, vol. 17(4), pp. 493-514. DOI: 10.1057/mel.2014.33

${ }^{2}$ Postan M., Kushnir L. (2016) A method of determination of port terminal capacity under irregular cargo delivery and pickup. Eastern-European Journal of Enterprise Technologies, vol. 4, no. 3(82), pp. 30-37. DOI: 10.15587/1729-4061.2016.76285

${ }^{3}$ Malaksiano N. A. (2012) On the stability of economic indicators of complex port equipment usage. Actual Problems of Economics, vol. 12, pp. 226-233. 
indicators of complex port equipment usage" ${ }^{4}$ estimates of variations of operational parameters and stability of economic indicators of equipment working under conditions of unstable load were obtained.

Modern sea terminals are, as a rule, the centers of conjugation of several modes of transport: sea, railway and automobile ${ }^{5,6}$. Therefore, the organization of interaction between different modes of transport is of great importance in terms of performance indicators of the terminal. There are a number of works devoted to studying these issues ${ }^{7}$.

The ways of increasing the efficiency of the sea transportations were investigated by I. Lapkina, M. Malaksiano, V. Glavatskih and others, ${ }^{8,9,10}$. Methodology for substantiating the choice of vessels, taking into account the possibility of their operation for transportation of oversized project cargo and work at slow speeds was developed by M. Malaksiano and O. Melnyk ${ }^{11,12}$.

${ }^{4} \mathrm{Hu}$ Q., Wiegmans B., Corman F., Lodewijks G. (2019) Integration of inter-terminal transport and hinterland rail transport. Flexible Services and Manufacturing Journal, vol. 31(3), pp. 807-831. DOI: 10.1007/s10696-019-09345-8

5 Panchenko S., Butko T., Prokhorchenko A., Parkhomenko L., Zhurba O. (2018) Development of rational rail network topology for high-speed and conventional trains based on bacterial foraging optimization. International Journal of Engineering \& Technology, vol. 7(4.3), pp. 217-221. DOI: dx.doi.org/10.14419/ijet.v7i4.3.19790

${ }^{6}$ Lomotko D. V., Alyoshinsky E. S., Zambrybor G. G. (2016) Methodological Aspect of the Logistics Technologies Formation in Reforming Processes on the Railways. Transportation Research Procedia, vol. 14, pp. 2762-2766. DOI: 10.1016/j.trpro.2016.05.482

${ }^{7}$ Lapkina I., Malaksiano M., Glavatskih V. (2019) To the issue of the possibility of operating vessels at slow speeds. Scientific notes of Taurida National V.I. Vernadsky University. Series: Technical Sciences, vol. 30(69), no. 4, part 2, pp. 134-140. DOI: $10.32838 / 2663-5941 / 2019.4-2 / 22$

${ }^{8}$ Lapkina I. A., Malaksiano N. A. (2019) Mnogokriterial'nyy podkhod k obosnovaniyu vybora proekta priobreteniya i ekspluatatsii sudna-balkera [A multi-criteria approach to justifying the choice of a project of bulk carrier vessel acquiring and operating]. Transport Systems and Technologies: Collection of scientific works of the State University of Infrastructure and Technologies, vol. 2, no. 33, pp. 99-110. DOI: 10.32703/2617-9040-2019-33-2-10

9 Lapkina I. O., Malaksiano M. O. (2019) O vybore sudna s uchetom izmeneniy konyunktury frakhtovogo rynka i tseny na toplivo [On the choice of vessel, taking into account changes in the freight market and fuel prices]. Herald of the Odessa National Maritime university: Collection of Scientific Papers, issue 1 (58), pp. 184-198.

10 Malaksiano M., Melnyk O. (2020) Vessel selection prospects and suitability assessment for oversized cargo transportation. Scientific notes of Taurida National V. I. Vernadsky University. Series: Technical Sciences, vol.31(70), no. 1, part 2, pp. 135-140. DOI: 10.32838/2663-5941/2020.1-2/25

11 Malaksiano M. O., Melnyk O. M. (2020) Obghruntuvannja vyboru sudna dlja frakhtuvannja na umovakh tajm-charteru vrakhovujuchy mozhlyvistj jogho vykorystannja dlja perevezenj neghabarytnykh vantazhiv [Vessel choice justification for chartering on a time-charter basis, considering feasibility for oversized cargo shipment]. Visnyk of Vinnytsia Polytechnical Institute, no. 1, pp. 90-96. DOI: 10.31649/1997-9266-2020-148-1-90-96 
O. Akimova and O. Melnyk ${ }^{13,14,15,16}$ analyzed the current state of research in the field of organization and improvement of oversized cargo transportation and considered the prospects for further research with the development of modern models of management of oversized cargo transportation to Ukraine using river-sea transport.

Despite the significant development of classical mathematical methods of operations research, the range of practical problems, for which they can be effectively applied, are quite limited. Therefore, in many cases, in the study of complex transport systems application of simulation methods is the most appropriative. A decision support system based on simulation modeling to optimize shipyard operations was developed by E. Hadjiconstantinou ${ }^{17}$, taking into account all cargo flows through the shipyard in order to improve the efficiency of container terminal operations. Problems associated with optimization of sea port terminals based on the trends in the intensity and structure of the cargo flow, specifics of cargo handling operations and navigation conditions, were carried out by I. Lapkina, M. Malaksiano and Y. Savchenko ${ }^{18,19}$ using simulation modeling methods. To optimize the system of perishable cargo delivery through the port of Odessa, a discrete event

12 Akimova O. V., Melnyk O. M. (2018) Организационные аспекты перевозки проектных грузов [Organizational aspects of the project cargo transportation]. Herald of the Odessa National Maritime university: Collection of Scientific Papers, issue 3(56), pp. 123-134.

${ }^{13}$ Melnyk O. (2019) Oghljad stanu doslidzhenj problemy perevezenj neghabarytnykh vantazhiv v Ukrajini [Overview of research status of the problem of transportation of oversized cargoes in Ukraine], Transport Systems and Technologies: Collection of scientific works of the State University of Infrastructure and Technologies, issue 34, pp. 242-253. DOI: $10.32703 / 2617-9040-2019-34-2-7$

14 Melnyk O. (2019) Problems statement and prospects for the development of oversized cargoes transportation in Ukraine. Shipping \& Navigation, issue 29, pp. 142-153. DOI: $10.31653 / 2306-5761.29 .219 .142-153$

15 O. Melnyk (2019) Pytannja zabezpechennja bezpeky procesu morsjkogho perevezennja neghabarytnykh vantazhiv [Safety issues of oversized cargoes transportation by sea]. Municipal Economy of Cities, vol. 6, no. 152, pp. 204-208. DOI: 10.33042/25221809-2019-6-152-204-208

16 Hadjiconstantinou E., Ma N. L. (2009) Evaluating straddle carrier deployment policies: a simulation study for the Piraeus container terminal. Maritime Policy \& Management, vol. 36(4), pp. 353-366. DOI: 10.1080/03088830903056991

${ }^{17}$ Lapkina I. O., Malaksiano M. O., Savchenko Y. S. (2018) Proektuvannja ta optymizacija transportnykh system z vykorystannjam metodiv imitacijnogho modeljuvannja [Design and optimization of transport systems by means of simulation modeling]. Herald of the Odessa National Maritime university: Collection of Scientific Papers, issue 3 (56), pp. 80-91.

${ }^{18}$ Lapkina I., Malaksiano M., Savchenko Y. (2020) Design and optimization of maritime transport infrastructure projects based on simulation modeling. Proceedings of the 1st International Workshop IT Project Management (Ukraine, Slavsko, February 18-20, 2020), Slavsko: ITPM 2020, pp. 36-45.

${ }^{19}$ Lapkina I. O., Malaksiano M. O. (2016) Modelling and optimization of perishable cargo delivery system through Odesa port. Actual Problems of Economics, issue 3, pp. 353-365. 
simulation model was implemented by I. Lapkina, M. Malaksiano ${ }^{20}$. R. Cimpeanu, M. Devine and C. O'Brien ${ }^{21}$ developed a simulation model to analyze bulk cargo unloading, as well as the transportation, storage and offloading of materials at Europe's largest alumina refinery, RUSAL Aughinish Alumina. Another simulation model was implemented by A. Baldassarra, S. Impastato and S. Ricci ${ }^{22}$ in order to replicate the work performed in the intermodal container terminal, as well as to calculate the total time of transportation and to identify bottlenecks. There are a number of other publications in which the simulation approach has been successfully applied to study complex systems, including those related to transport and logistics. And despite the large number of publications, as well as the ever-growing interest in this area, a number of practically important issues still remain underresearched. As part of the business project study, our team investigated the performance of the Emden Ro-Ro port terminal with various options for its upgrading under various traffic flow scenarios. Located in the depths of the River Ems, this terminal is a major Ro-Ro cargo hub with a daily carrying capacity of over 5,000 export and import vehicles (Fig. 1-3).

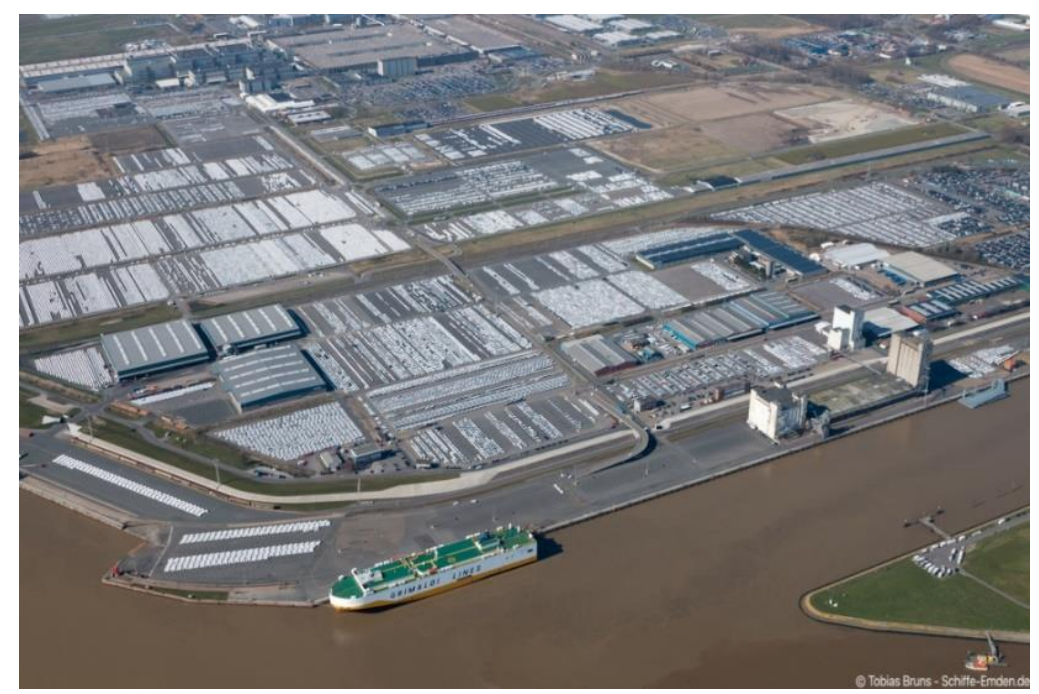

Fig. 1. Warehouse spaces of the Ro-Ro terminal of the port of Emden ${ }^{23}$

${ }^{20}$ Cimpeanu R., Devine M. T., O’Brien C. (2017) A simulation model for the management and expansion of extended port terminal operations. Transportation Research Part E: Logistics and Transportation Review, vol.98, pp. 105-131. DOI: $10.1016 /$ j.tre.2016.12.005

${ }^{21}$ Baldassarra A., Impastato S., Ricci S. (2010) Intermodal terminals simulation for operation management. European Transport, Institute for the Study of Transport within the European Economic Integration, vol. 46, pp. 86-99.

22 Emder Hafen Luftaufnahmen Luftbild Emden-2329. URL: https://schiffe-emden.de/fotostrecke-der-emder-hafen-von-oben/emder-hafenluftaufnahmen-luftbild-emden-2329/ (accessed 2019/11/20)

${ }_{23}$ Volkswagen exports at German port. URL: http://www.abc.net.au/news/2018-0623/volkswagen-exports-at-german-port/9902388 (accessed 2019/11/20) 
In assessing the performance of the terminal, it was necessary to consider and integrate the schedule of shipping lines, the nature of cargo flows, the characteristics of the terminal and the prevailing natural conditions of river navigation.

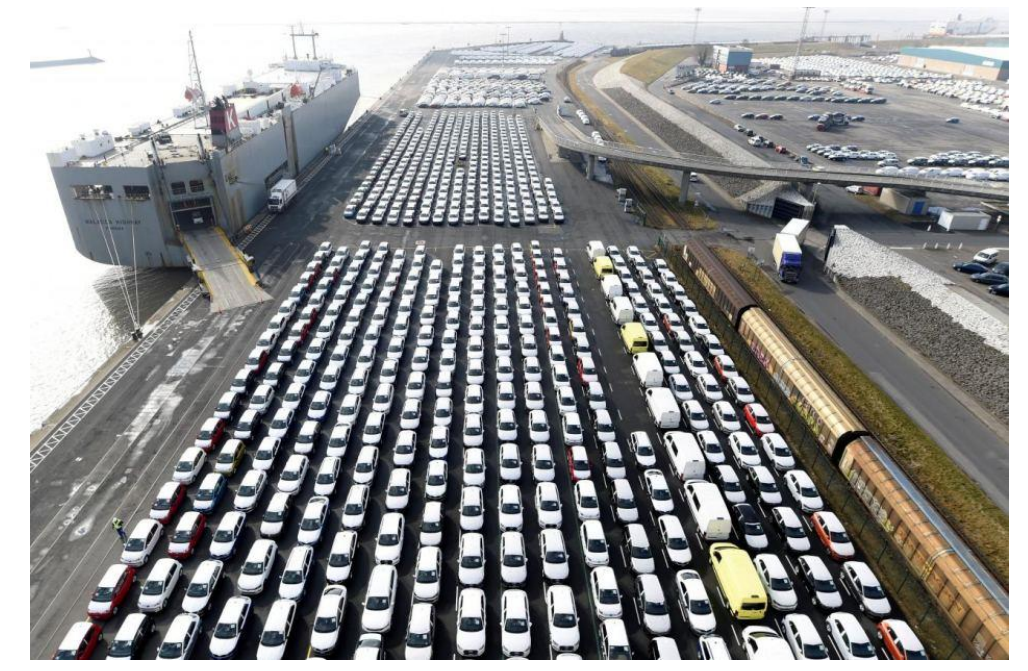

Fig. 2. Ship loading at the Ro-Ro terminal of the port of Emden ${ }^{24}$

Due to the daily high tide (Fig. 4, 5), the movement of deep-drafted vessels along the Ems River is limited for a significant part of the day. In order to reach the berths of the port, vessels have to be at a certain point in time, maintain a certain speed limit and eventually meet with tugboats for mooring.

The movement of vessels from the anchorage point to the terminal berths takes on average about 3.5 hours. The depth of the river fairway varies from $14.23 \mathrm{~m}$ to $10.5 \mathrm{~m}$. The amplitude of water level changes due to tidal movement exceeds $6 \mathrm{~m}$. Vessels unable to pass through the estuary before low tide have to wait at the roadstead or at the pier in order to reach the next tide.

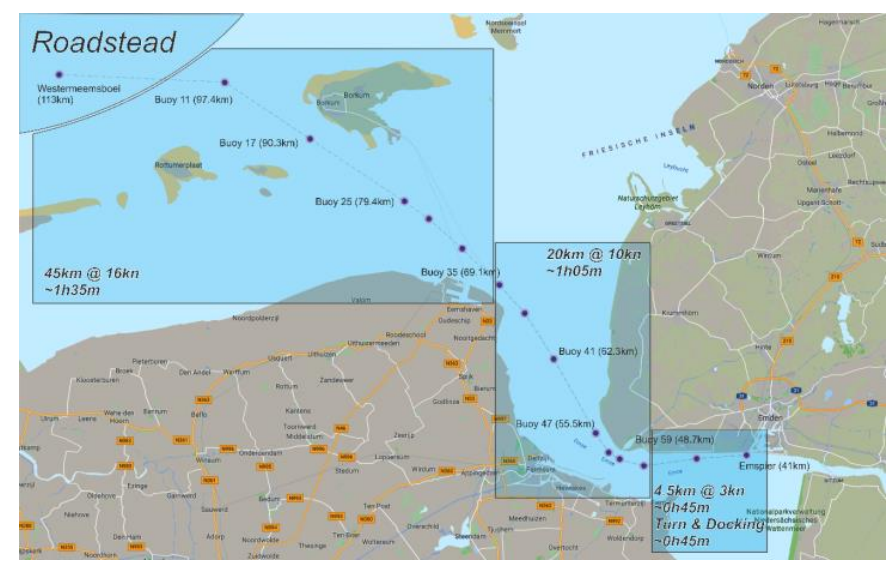

Fig. 3. Vessels traffic scheme to the Ro-Ro terminal of the port of Emden ${ }^{25}$

24 Google Maps. URL: https://www.google.com/maps/@53.3932007,6. 754134,11 $\mathrm{z}$ ?hl=en\&authuser=0 (accessed 2019/11/20) 
This has a significant impact on the terminal operations and makes it difficult to predict the key performance indicators values of the terminal in the event of increased intensity or irregularity of cargo movements as well as increased draft from inbound vessels.

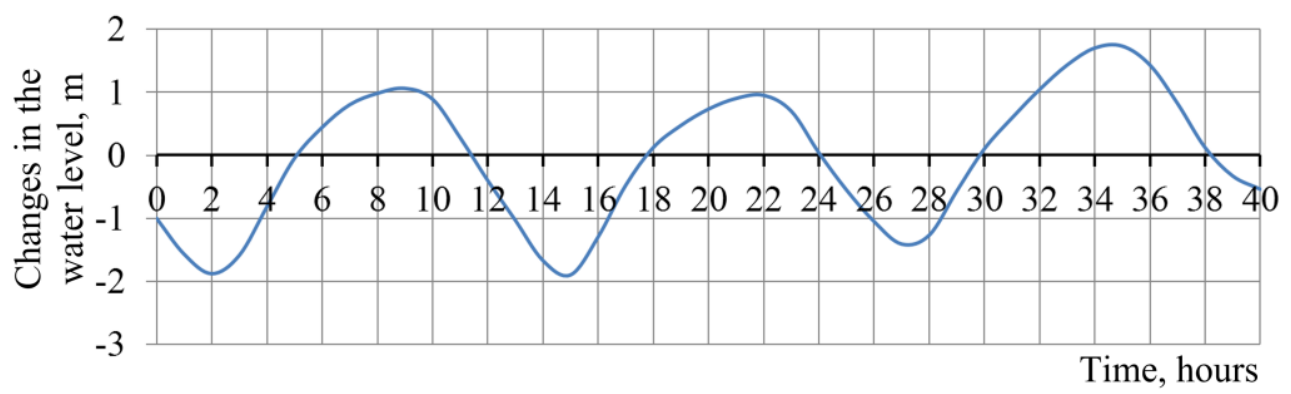

Fig. 4. The graph fragment of water level changes near the Ro-Ro terminal, the port of Emden (hour scale)

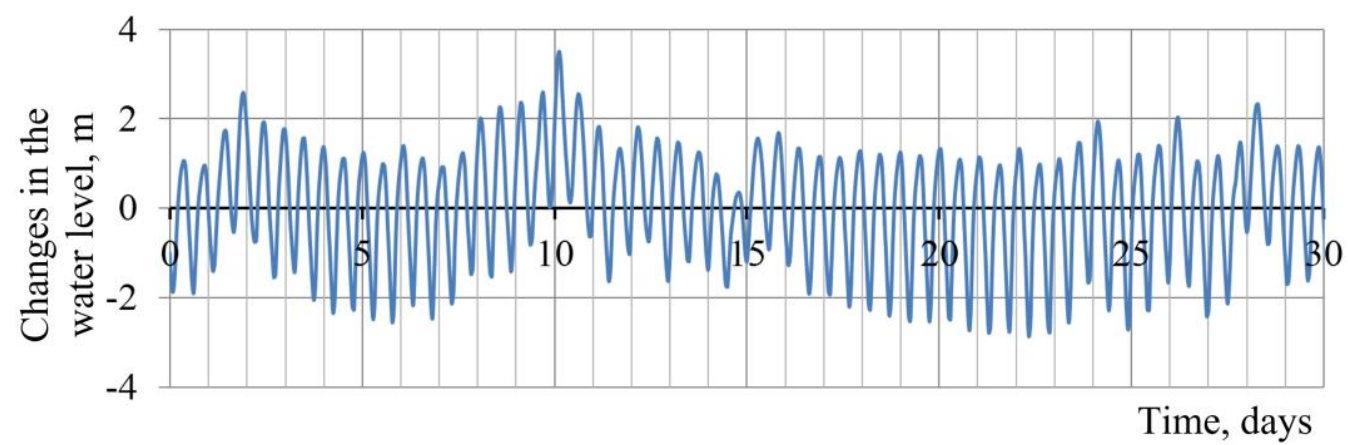

Fig. 5. The graph fragment of water level changes near the Ro-Ro terminal, the port of Emden (day scale)

Basing on possible changes in cargo structure and vessel traffic, it was necessary to consider several options for modernization of the terminal infrastructure. In our approach, we assessed the performance of the terminal and the stability of each of the modernization options, taking into account all possible changes. The construction of an additional deep-water jetty (Fig. 6), various dredging options, increased stevedoring intensity and variety of combinations of these measures were considered as a possible option for upgrading the terminal.

By reason of that classical analytical methods of queue theory and optimal control methods do not allow to investigate the problem in full, modeling methods were used. The discrete event simulation model was implemented as a separate application software with a graphical interface, data input, verification and output functions, as well as three-dimensional animation.

25 Port of Emden. URL: http://www.seaports.de/virthos.php?en//HOME/ HAFENSTANDORTE/Emden (accessed 2019/11/20) 

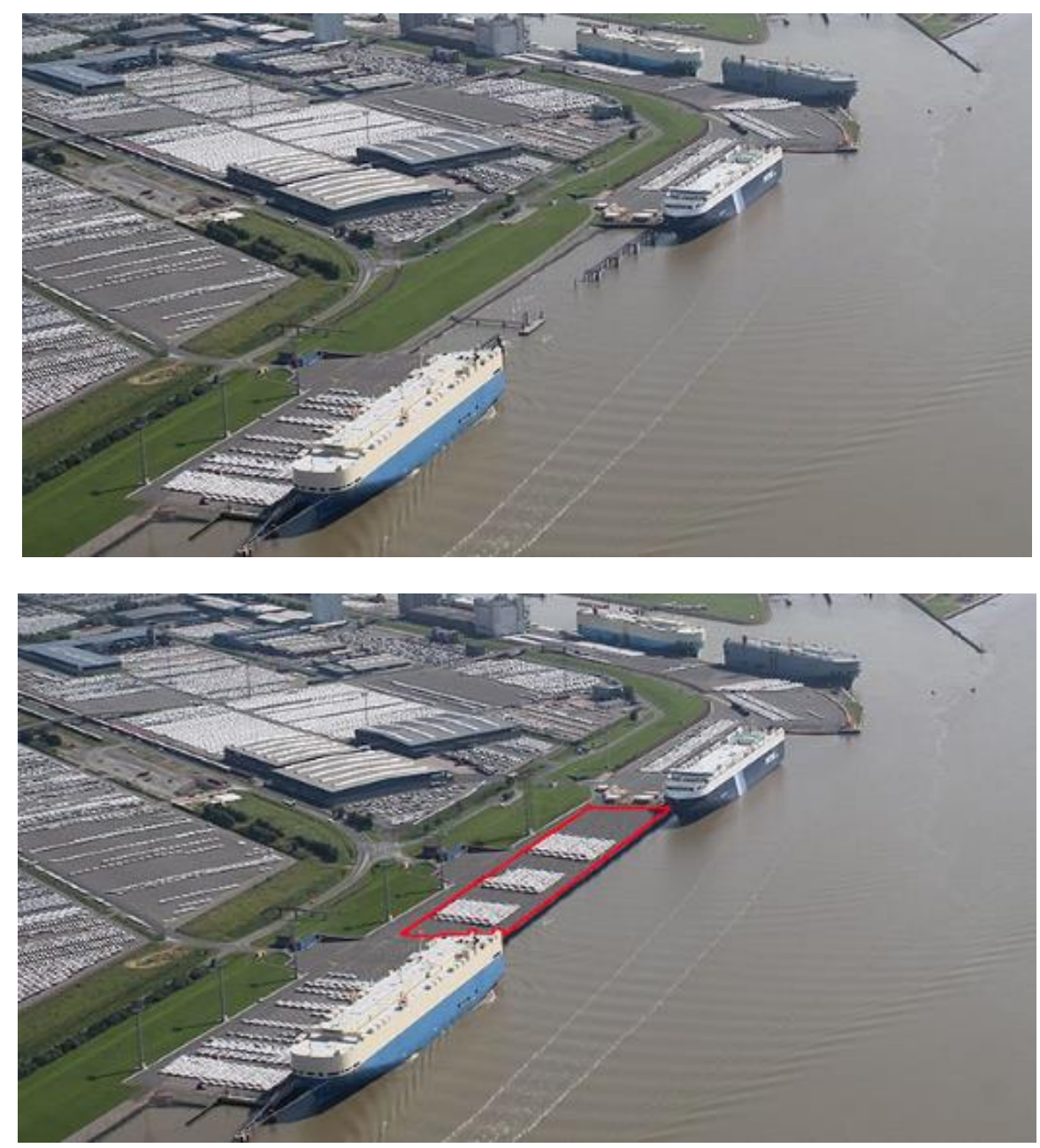

Fig. 6. Emden Ro-Ro terminal before and after the planned construction of an additional deep-water berth ${ }^{26}$

Immediately after start-up, the program reads the input parameters of the model from the corresponding structured file. This file contains all information about terminal modernization parameters, cargo flow change scenarios, schedules of vessel calls, number and capacity of tugboats, operation of stevedoring personnel, general simulation model parameters, etc. One single input data file corresponds to a specific scenario variant of the terminal modernization and cargo flow development. Such file contains more than 500 model parameters. Given the large number of input parameters, to prevent possible errors in data in-put, the program checks and thoroughly analyzes the input data for integrity, correctness and consistency before starting the simulation. If inaccurate or inconsistent information is found in the input data file, the program helps to correct it.

${ }^{26}$ Adkins R., Paxson D. (2017) Replacement decisions with multiple stochastic values and depreciation. European Journal of Operational Research, vol. 257, no. 1, pp. 174-184. DOI: 10.1016/j.ejor.2016.07.006 
The proposed simulation model can work both in single-pass mode with 3D-animation and in high-speed multi-pass mode without visualization. When working in 3D presentation mode, the model displays real-time animation of processes taking place in the terminal (Fig. 7, 8). Fig. 8 shows the working windows of the simulation model, working in a single mode, with a $3 \mathrm{D}$ presentation that displays one of the options for modification of the terminal. In the upper part of the model window there is a dynamic water level graph. Right below the water level chart there is a dynamic chart, where we can see the commencement and the completion of each stevedoring shift. It is also possible to monitor how the terminal redistributes stevedoring gangs between berths during operation, while observing the intensity of loading and unloading operations at each berth of the terminal at the same time. Cylindrical columns of blue and red above the berths in the 3D presentation window show the status of the loading/unloading process. Indicators depicted above the buoys along the fairway show the change in the current water level in different parts of the vessel's route. Simulation of the water level in the river at each point of time was performed with an error of $\pm 0.01 \mathrm{~m}$.

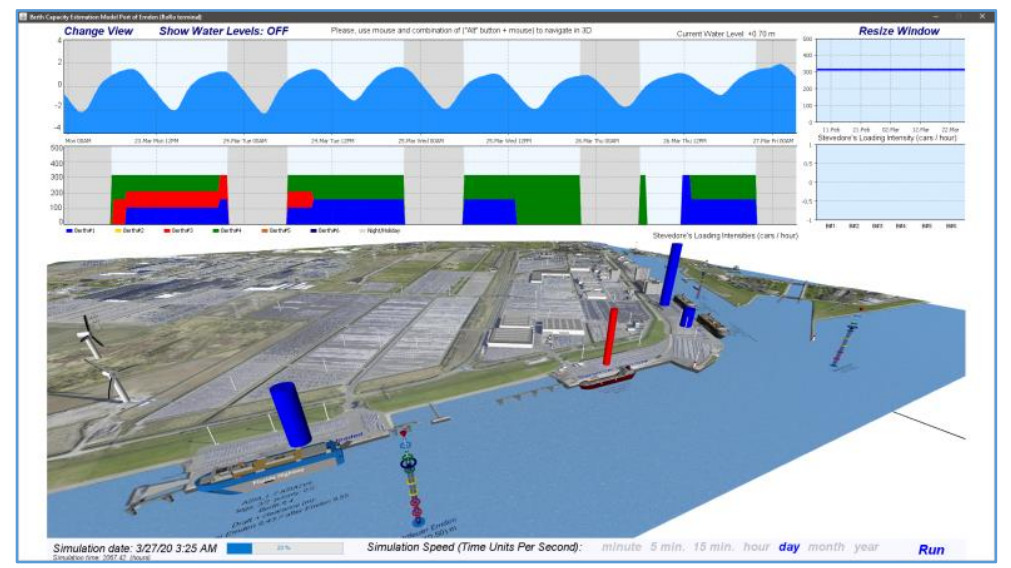

Fig. 7. Simulation model window during the run in the 3D presentation mode - the basic version

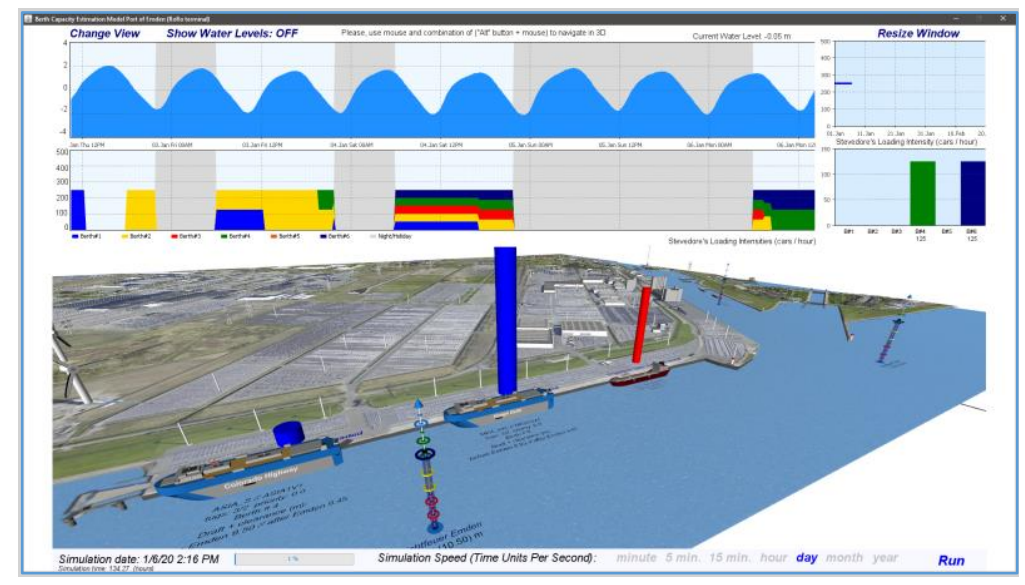

Fig. 8. Simulation model window during the run in the $3 \mathrm{D}$ presentation mode - the project version 
Creating a simulation model, the algorithms that simulate the work of the traffic control services of the terminal were implemented. The developed algorithms made it possible to regulate movement of vessels along the Ems river most effectively taking into account changes in the water level in each section of the fairway, as well as to control the operation of the tugboat fleet.

Much attention was paid to reproduce the schedules of vessel calls with high accuracy - technical characteristics of the ships, loading and unloading rates as well as seasonal changes in cargo traffic and possible effects of random factors were taken into consideration.

The model allows to display the movement of vessels operating on linear services whose voyages are executed in accordance with a fixed schedule on certain destinations as well as the movement of tramp vessels with a random appearance.

There is also a prioritization mechanism used for different groups of vessels and different destinations, the priorities can be set for selected shipping services or berths, and the substitution rules were provided.

Along with the design of business logic, the development of algorithms and visualization tools, the most important aspect of creating this simulation model was the choice of the structure of input data and the organization of data input and output. On one hand, the chosen structure of the input data allowed to reproduce the specified schedules of vessel calls quite accurately so that it was possible to check the adequacy of the model on the actual data of previous years, and also it was possible to investigate the operation of the terminal in the short-term prospects. On the other hand, the proposed structure of the input data made it possible to effectively specify scenarios of cargo traffic that are likely in the distant future and for which there are no exact schedules of vessels, but only a specification of trends.

Much attention was paid to measures that contribute to maintaining the integrity and correctness of the input data. For this, firstly, various visual tools, comments and contextual prompts that appear while editing the input data file were used to help make data entry more convenient and more intuitive. Secondly, a two-level verification of the input information was implemented. The first level of verification was implemented at the stage of editing the input data file. At this level, most typos and apparent inconsistencies are detected and corrected. The second level of input data verification is carried out by the simulation model right before the start of the model run. At the second level, series of more complex checks and test calculations are carried out, aimed at detecting non-surface logical inconsistencies and contradictions.

After completion of the run, the model generates output file containing both the general statistical indicators of the terminal operation for a given 
period of time as well as detailed protocol with a record of all events that occurred at the terminal during the run of the model. Analyzing this file, one can, firstly, check the adequacy of the work of all elements of the model, and secondly, track the occurrence of crisis phenomena, observe the appearance of queues and analyze the circumstances that caused it. It also allows to evaluate how quickly the system is able to overcome crisis situations and the lack of resources at the same time. Random number generators can be configured in the model so that all the processes occurring on the terminal are reproduced in the same way from start to finish. This allows us to see how well the system is able to cope with the same crisis conditions in various terminal upgrade options. Additionally, random number generators can be configured so that each launch creates a unique sequence of random events. This mode is useful while studying the stability of the terminal performance.

The most important information about the performance and stability of the terminal operations can be obtained by analyzing a series of runs of the simulation model under various options for its modernization. The simulation model algorithms are optimized in the way so that it takes less than one second to run a single scenario within one year of model time. This makes possible to carry out numerous series of tests and crate on their basis the set of statistical conclusions or use various numerical algorithms to find the optimal parameters for the modernization of the concerned terminal. Upon completion, the model saves all the resulting data of series of runs to a respective output file.

On the basis of the analysis of statistical data obtained as a result of numerous repeated runs of the simulation model, it is possible to estimate the average value of key performance indicators in various situations, in the future - resistance to possible fluctuations in freight flows and random deviations in the traffic schedule, thus, the deficiencies of the considered transport system were identified. A number of estimates have been obtained for different freight flow scenarios and various options for modernization of the terminal, such as average ship's downtime on the raid, values of berth employment ratios, etc. Distribution density functions for the values of key performance indicators and confidence intervals for their assets have been defined.

A series of runs were conducted in order to assess how well the various options for the development of the terminal will function in conditions of increasing cargo flow. The results were used to build appropriate charts of the values of the key performance indicators. The diagram on the Fig. 9 shows the berthing time for only four alternative options for upgrading the terminal infrastructure with a gradual increase in traffic. 


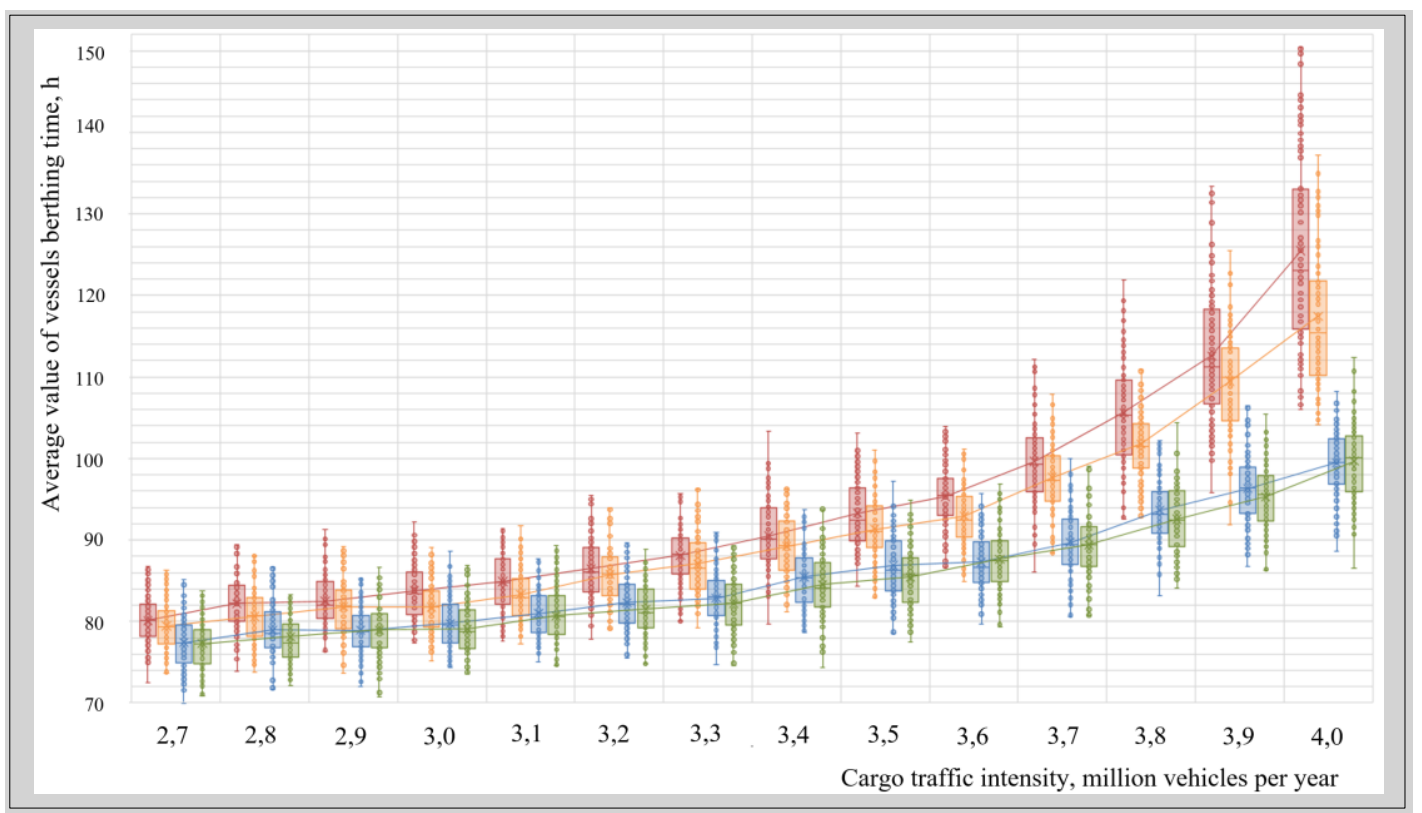

Fig. 9. Changes in the average value of vessels berthing time for the three options of the terminal development according to changes of cargo traffic intensity

Each of the points depicted in this figure shows the average vessel berthing time for one run of the simulation model, which corresponds to one year of operation of the terminal. Each box shows the values between the upper and lower quartiles of the sample of mean values of the average vessel berthing time obtained at a given cargo flow intensity for a given terminal development option. Fluctuations of values within the box are due to random events and inconsistencies in the working time of stevedores, the schedules of the ships as well as tides etc. The curves on Fig. 9 reflect changes in the average values of vessels berthing time for all runs, depending on the intensity of cargo throughput.

Note: Fig. 9 should be taken only as a schematic indication that presents implemented methodology in this research project. Due to commercial secrecy, publication of actual trade data and detailed simulation conclusions is not possible. Therefore, the data shown in Fig. 9, were intentionally modified. The figure also illustrates the overall trend of changes in the mean and the level of stability for the quality of service of the ships identified in the study.

It can be seen from the Fig. 9 that at a low intensity of cargo traffic (from 2.7 to 3.5 million vehicles per year), there is a slight gradual increase in the average vessel berthing time. At the same time, all four curves of the mean values are almost parallel, and the degree of variation of the average vessel berthing time is rather small and almost the same for all four variants of terminal modernization. But with a significant increase in cargo traffic intensity (more than 3.7 million vehicles per year), there is a significant nonlinear increase in both the average value and the degree of scatter in the 
first and second variants of terminal upgrades. At the same time, with the third and fourth variants of the terminal changes, both the mean values and the range of values are increasing at a much slower rate.

\section{ELABORATION OF SEA PORT EQUIPMENT MODERNIZATION TERMS}

Modernization and timely updating of equipment is an important factor determining the effective development of many enterprises. Therefore, the development of methods for substantiating the optimal service life of equipment is of great practical interest. In articles by R. Adkins, D. Paxson, I. Lapkina and M. Malaksiano ${ }^{27,28,29}$, the optimum terms of equipment replacement under the conditions when operating costs of equipment are subject to random fluctuations have been investigated. Also the issues of the influence of tax rates on the determination of optimum terms of equipment utilization have been studied by R. Adkins and D. Paxson. The influence of random fluctuations in the equipment utilization rate on the optimum service life has been examined by I. Lapkina and M. Malaksiano ${ }^{30,31,32,33,34,35}$.

${ }^{27}$ Lapkina I., Malaksiano M. (2018) Estimation of fluctuations in the performance indicators of equipment that operates under conditions of unstable loading. EasternEuropean Journal of Enterprise Technologies, vol. 1, no. 3 (91), pp. 22-29. DOI: $10.15587 / 1729-4061.2018 .123367$

28 Malaksiano N. A. (2013) Ispol'zovanie mnogokriterial'nykh otsenok dlya umen'sheniya riskov pri planirovanii remontov i zamen slozhnogo portovogo oborudovaniya, funktsioniruyushchego $\mathrm{V}$ usloviyakh nepolnost'yu opredelennogo gruzopotoka [The use of multicriteria assessments to reduce risks when planning repairs and replacements of complex port equipment operating in conditions of incompletely defined cargo flow]. Methods and Tools for Managing the Development of Transport Systems: Collection of Scientific Papers Odessa National Maritime University, no. 1(20), pp. 7-27.

${ }^{29}$ Malaksiano M. O. (2012) On the optimal repairs and retirement terms planning for complex port equipment when forecast level of employment is uncertain. Economic Cybernetics, issue 4-6(76-78), pp. 49-56.

${ }^{30}$ Malaksiano M. O. (2013) Vybir strateghiji remontiv i zamin skladnogho obladnannja, shho funkcionuje $\mathrm{v}$ umovakh nepostijnoji zajnjatosti [Choosing a strategy for repairs and replacements of complex equipment that operates under condition of unstable employment]. Herald of Khmelnytskyi National University. Economic sciences, issue 1, pp. 215-221.

${ }^{31}$ Malaksiano N. A. (2012) O vliyanii urovnya zanyatosti portovogo oborudovaniya na dinamiku ego iznosa [On the influence of the level of employment of port equipment on the dynamics of its depreciation]. Methods and Tools for Managing the Development of Transport Systems: Collection of Scientific Papers Odessa National Maritime University, no. 19, pp. 7-19.

${ }^{32}$ Lapkina I. O., Malaksiano M. O. (2018) Opredelenie srokov zameny oborudovaniya s uchetom iznosa i izmeneniy ego rynochnoy stoimosti [Determination of replacement terms of equipment taking into account deterioration and changes of its market value]. Herald of the Odessa National Maritime university: Collection of Scientific Papers, issue 4 (57), pp. 188-201. 
The issues of determining the optimum service life of equipment, based on the possibility of restoration have been investigated by S. Stutzman, B. Weiland and others ${ }^{36}$. Thus, the possibility of a single equipment repair with a subsequent replacement for a coal-fired power plant has been considered.

The problem of finding the optimum terms of equipment replacement taking into account taxation and the depreciation policy has been investigated by J. Zambujal-Oliveira and J. Duque ${ }^{37}$. For this, the mathematical model based on a partial differential equation has been proposed. For the modeling of random fluctuations, the Brownian process has been used. Failures of complex multi-component technical systems have been studied by B. Liu, J. Wu and $\mathrm{M}$. Xie ${ }^{38}$. Thus, the influence of the technical system configuration, quality of elements and interaction between them on failures of the entire system and changes in associated costs has been analyzed. Models of cost estimation for systems with various configurations of elements have been presented and a sensitivity analysis has been carried out. At the same time, the issues related to obsolescence of equipment remained beyond the scope of these studies.

The problems of stable functioning of transport systems under conditions of uneven cargo traffic and the rationale for the choice of the optimum structure of the equipment fleet have been investigated by I. Lapkina and M. Malaksiano ${ }^{39}$.

${ }^{33}$ Lapkina I. O., Malaksiano M. O. (2018) O povyshenii ustoychivosti pokazateley effektivnosti pri planirovanii srokov obnovleniya slozhnogo oborudovaniya [On improving the sustainability of indicators of effectiveness at the planning of the update of completing equipment updates]. Herald of the Odessa National Maritime university: Collection of Scientific Papers, issue 1 (54), pp. 207-217.

${ }^{34}$ Malaksiano M. O. (2012) Ob optimal'nykh srokakh remontov slozhnogo portovogo oborudovaniya [On the optimal timing of repairs of complex port equipment]. Herald of the Dnepropetrovsk National University. Series Economics, issue 6(3), pp. 186-195.

35 Stutzman S., Weiland B., Preckel P., Wetzstein M. (2017) Optimal replacement policies for an uncertain rejuvenated asset. International Journal of Production Economics, vol. 185, pp. 21-33. DOI: 10.1016/j.ijpe.2016.12.018

${ }^{36}$ Zambujal-Oliveira J., Duque J. (2011) Operational asset replacement strategy: A real options approach. European Journal of Operational Research, vol. 210, issue 2, pp. 318-325. DOI: 10.1016/j.ejor.2010.09.011

${ }^{37}$ Liu B., Wu J., Xie M. (2015) Cost analysis for multi-component system with failure interaction under renewing free-replacement warranty. European Journal of Operational Research, vol. 243, issue 3, pp. 874-882. DOI: 10.1016/j.ejor.2015.01.030

${ }^{38}$ Lapkina I. O., Malaksiano M. O., Malaksiano M. O. (2016) Optimization of the structure of sea port equipment fleet under unbalanced load. Actual Problems of Economics, issue 9, pp. 364-371.

${ }^{39}$ Hagspiel V., Huisman K. J. M., Nunes C. (2015) Optimal technology adoption when the arrival rate of new technologies changes. European Journal of Operational Research, vol. 243, issue 3, pp. 897-911. DOI: 10.1016/j.ejor.2014.12.024 
The work by V. Hagspiel, K. Huisman and C.Nunes ${ }^{40}$ is devoted to planning the terms of introduction of new technologies. The models and conclusions proposed in it are based on certain assumptions regarding the rates of technological progress and emergence of new technologies.

The issues of early and delayed replacement of equipment in the deterministic model with the account for technological progress have been studied by R. Adkins and D. Paxson ${ }^{41}$. It has been assumed that the level of income and expenses associated with equipment varies over time. The optimum time of deterministic replacement of equipment has been determined using the dynamic programming model.

The issues of determining the optimum time of the introduction of advanced equipment in view of uncertainty of the time of emergence of new technologies and their efficiency have been studied by M. Chronopoulos and A. Siddiqui ${ }^{42}$. Three strategies of introduction of technological innovations have been considered. The substantiation of the choice of a strategy at various levels of uncertainty, efficiency, and also the pace of technological innovation has been carried out.

In order to justify the time of equipment replacement taking into account available spare parts stocks and considering the technical progress, it has been proposed by T. Nguyen, T. Yeung and B. Castanier ${ }^{43}$ to use the model of the Markov decision process. It has been assumed that due to technical progress in the market, new types of equipment may appear over time. But when replacing old equipment with new equipment, spare parts for old equipment become useless.

In a number of works, when determining the optimum terms of equipment replacement, only the factor of wear and tear or only the factor of emergence of new technologies were taken into consideration. Also, many authors emphasize the need to study the influence of the random factor in justifying the equipment replacement terms. In the above-mentioned works, only some of the

40 Adkins R., Paxson D. (2013) Deterministic models for premature and postponed replacement. Omega, vol. 41, issue 6, pp. 1008-1019. DOI: 10.1016/j.omega.2013.01.002

${ }^{41}$ Chronopoulos M., Siddiqui A. (2014) When is it Better to Wait for a New Version? Optimal Replacement of an Emerging Technology under Uncertainty. Norwegian School of Economics, Department of Business and Management Science, Retrieved: https://brage.bibsys.no/xmlui/bitstream/handle/11250/217638/1/DiscussionPaper.pdf (accessed 2019/11/20)

${ }^{42}$ Nguyen T. P. K., Yeung T. G., Castanier B. (2013) Optimal maintenance and replacement decisions under technological change with consideration of spare parts inventories. International Journal of Production Economics, vol. 143, issue 2, pp. 472-477. DOI: 10.1016/j.ijpe.2012.12.003

${ }^{43}$ Lapkina I., Malaksiano M. (2018) Elaboration of the equipment replacement terms taking into account wear and tear and obsolescence. Eastern-European Journal of Enterprise Technologies, vol. 3, no. 3 (93), pp. 30-39. DOI: 10.15587/1729-4061.2018.133690 
above factors have been in a varying degree considered. At the same time, in a number of cases, it is necessary to fully consider the aggregate of all these factors when making decisions on equipment replacement. Therefore, the issues related to justifying the equipment replacement terms on the basis of a comprehensive assessment of both wear and tear and obsolescence, as well as accounting for the random factor, are of great importance ${ }^{44}$.

The aim of the study is to develop methods of planning the optimum terms of replacement of wearing equipment with more advanced equipment of new type, taking into account the degree of dispersion of possible values of equipment performance indicators.

The situation when the operating mode and utilization rate of equipment remain constant throughout the life, and all technical and operational characteristics are governed by the relevant regulations is considered. If technical and operational characteristics cease to meet specified standards of performance, reliability or safety over time, then the use of such equipment is considered unacceptable, and it must be repaired or replaced. For example, this applies fully to seagoing vessels: their usage modes are constant, and the technical condition is strictly controlled by the maritime register. It is economically irrational to use a seagoing vessel not with full intensity because it has rather high fixed costs, which can only be covered by intensive use. The situation is similar with railway rolling stock. The same situation is with complex handling equipment of sea ports. So, reducing the operating time of an aging harbor crane or reducing the speed of the harbor crane entails the irrational use of the berth, warehouse and dockers, increases the costly unproductive time of vessel berthing in the port. For such equipment, operating costs associated with the growth in the number of maintenance and repair works usually increase over time, while performance and reliability must remain at a certain level.

The main criterion in making decisions on replacement of such equipment, as a rule, is the change in the economic performance of its operation. It is often difficult to estimate the profit share of the entire enterprise, which falls on a particular machine, if this machine is only a part of a complex production chain. Therefore, it is natural to consider the unit cost of equipment operating time (or unit cost) or indicators that are derivatives of the unit cost as an indicator of equipment performance under such conditions. The EAC indicator reflects the redistributed share of total costs of equipment per unit operating time. At the same time, EAC considers cash flow discounting, which is a mandatory requirement in case of complex equipment having a long service

${ }^{44}$ Jones T. W., Smith D. (1982) An historical perspective of net present value and equivalent annual cost. Accounting Historians Journal, vol. 9, no. 1, pp. 103-110. DOI: 10.2308/0148-4184.9.1.103 
life ${ }^{45}$. The use of the $E A C$ indicator does not require reduction to a single planning horizon when comparing the results of utilization of equipment with different service lives. With such problem statement, NPV, IRR and many other widely used indicators for equipment performance assessment are not suitable. Therefore, the $E A C$ indicator was chosen in the paper as the main criterion for estimating the efficiency of complex port equipment.

In some cases, it may take a long time from the moment of making a decision to purchase complex equipment prior to commissioning. This is due to the fact that, as a rule, complex equipment, including complex seaport handling equipment, is made to order. The manufacture, transportation and installation of equipment, as well as previous stages associated with the preparation and approval of feasibility studies to obtain permits and attract investments for purchase, often take years. Therefore, the questions related to replacement of such equipment cannot be solved promptly, based only on the current condition of equipment or short-term forecasts. In many cases, replacement of such equipment should be planned long before its technical condition reaches an unsatisfactory level.

Thus, the delay between the control action (in this case, the decision to replace equipment) and the response of the control object (commissioning of new equipment) is too great. At the same time, the values of equipment performance indicators are subject to random fluctuations. Moreover, the values of performance indicators of equipment at the time of replacement often correlate little with the values of performance indicators at the time of making a replacement decision (for example, graphs of covariance functions of operating costs for container cranes are shown in Fig. 6 and 7). An apparatus for the synthesis and stability analysis of adaptive control systems is presented in the book by B.Anderson, R. Bitmead and others ${ }^{46}$. However, due to the above-mentioned features, it cannot be successfully used in some cases to solve the problem of finding the optimum terms for replacing complex equipment. In this paper, we propose a different approach to the study of this problem.

In most cases, equipment repair and maintenance payments are discrete and aggregated monthly, quarterly or annually. Therefore, when evaluating the equipment effectiveness post factum, discrete models are often used. However, continuous regression curves of possible changes in indicators and continuous optimization methods are more convenient for forecasting. Therefore, attention

${ }^{45}$ Anderson B. D. O., Bitmead R. R., Johnson C. R., Kokotovic Jr., P. Y., Kosut R. L., Mareels I. M. V., Praly L., Riedle B. D. (1986) Stability of adaptive systems: passivity and averaging analysis. MIT Press.

46 Podinovskiy V. V., Nogin V. D. (1982) Pareto-optimal'nye resheniya mnogokriterial'nyh zadach [Pareto-optimal solutions to multicriteria problems]. Moscow: Nauka. (in Russian) 
should be given to the development of an approach based on the use of continuous models.

The rationale for the choice of the $E A C$ indicator as an optimization criterion is presented in the paper by T. Jones and D. Smith "A historical perspective of net present value and equivalent annual cost".

Consider the situation where old equipment is replaced with more advanced equipment of comparable performance. We introduce the following notation:

$A_{o}$ - the cost of purchase and installation of old equipment, USD;

$A_{n}$ - the cost of purchase and installation of new equipment, USD;

$c_{o}(t)$ - the average rate of operating costs of old equipment after operation for $t$ years, USD/year;

$c_{n}(t)$ - the average rate of operating costs of new equipment after operation for $t$ years, USD/year;

$S_{o}(t)$ - the cost of dismantling and sale of old equipment after operation for $t$ years, USD;

$S_{n}(t)$ - the cost of dismantling and sale of new equipment after operation for $t$ years, USD;

$T_{o}$ - the time during which it is planned to use old equipment, years;

$T_{n}$ - the time during which it is planned to use new equipment, years.

Since the service life of complex equipment is typically several years, discounting should be used to assess the utilization efficiency throughout the life cycle. Let $r$ be the annual continuously compounded interest rate. Using the known continuous compounding formula, the current operating costs of old equipment when used for $T_{o}$ years can be found:

$$
P V\left(C_{o, \text { oper }}\left(T_{o}\right)\right)=\int_{0}^{T_{o}} c_{o}(\tau) \cdot e^{-r \cdot \tau} d \tau .
$$

The current capital costs of old equipment, when used for $T_{o}$ years, are found by the formula

$$
P V\left(C_{o, \text { cap }}\left(T_{o}\right)\right)=A_{o}+S_{o}\left(T_{o}\right) \cdot e^{-r \cdot T_{o}} .
$$

Thus, the current total costs of old equipment when used for $T_{o}$ are

$$
\begin{gathered}
P V\left(C_{o, \text { total }}\left(T_{o}\right)\right)=P V\left(C_{o, \text { cap }}\left(T_{o}\right)\right)+P V\left(C_{o, \text { oper }}\left(T_{o}\right)\right)= \\
=A_{o}+S_{o}\left(T_{o}\right) \cdot e^{-r \cdot T_{o}}+\int_{0}^{T_{o}} c_{o}(\tau) \cdot e^{-r \cdot \tau} d \tau .
\end{gathered}
$$


To substantiate the optimum service life of equipment, it is possible to use the current total costs of equipment in cyclic replacements with the same type of equipment during an infinite planning horizon $P V\left(C_{o, t o t a l}^{\infty}\left(T_{o}\right)\right)$. Summing up the terms of the geometric progression, it is easy to show that

$$
P V\left(C_{o, \text { total }}^{\infty}\left(T_{o}\right)\right)=P V\left(C_{o, \text { total }}\left(T_{o}\right)\right) \cdot \frac{1}{1-e^{-r \cdot T_{o}}} .
$$

To compare the equipment performance on time intervals of different lengths, the EAC (Equivalent Annual Cost) indicator is often used (for example, [45]). EAC equals the current value of equipment costs multiplied by the $\operatorname{CRF}\left(T_{o}, r\right)$ value (Capital Recovery Factor), where

$$
C R F\left(T_{o}, r\right)=\frac{e^{r}-1}{1-e^{-r \cdot T_{o}}} .
$$

In this case, the $E A C$ indicator, calculated on the basis of one complete utilization cycle of old equipment, is given by the formula

$$
E A C_{o}\left(T_{o}\right)=P V\left(C_{o, \text { total }}\left(T_{o}\right)\right) \cdot \frac{e^{r}-1}{1-e^{-r \cdot T_{o}}} .
$$

The equipment operation term $T_{o}^{*}$ in which the expression (4) or (6) will take a minimum value can be considered optimum. Although the formulas (4) and (6) reflect different performance indicators of equipment, it is obvious that they reach minimum values at the same value of $T_{o}=T_{o}^{*}$.

Similarly, it can be found that the optimum service life $T_{n}^{*}$ of new equipment, provided that it is replaced by equipment of the same type, is the minimum point of the expression

$$
E A C_{n}\left(T_{n}\right)=P V\left(C_{n, \text { total }}\left(T_{n}\right)\right) \cdot \frac{e^{r}-1}{1-e^{-r \cdot T_{n}}}
$$

where

$$
P V\left(C_{n, \text { total }}\left(T_{n}\right)\right)=A_{n}+S_{n}\left(T_{n}\right) \cdot e^{-r \cdot T_{n}}+\int_{0}^{T_{n}} c_{n}(\tau) \cdot e^{-r \cdot \tau} d \tau
$$

If at the same level of performance there is inequality $\operatorname{EAC}_{n}\left(T_{n}^{*}\right)<E A C_{o}\left(T_{o}^{*}\right)$ this gives grounds to consider that new equipment, when used in the given conditions, is economically more expedient than old equipment. 
Let us investigate the issue of finding the optimum terms of equipment replacement when switching from old equipment to new equipment, which is comparable in performance to old, but is more economically feasible. To this end, two reasoning patterns are considered: the first pattern, based on the analysis of a finite time interval consisting of two complete cycles of equipment replacement, and the second - based on an infinite time interval.

We consider the first pattern, based on the analysis of the time interval, consisting of two complete utilization cycles of equipment. Within this pattern, it is planned to use old equipment during the first cycle of $T_{o}$ years. Then it is planned to use new equipment during the second cycle of $T_{n}$ years. It is easy to see that the current total costs during these two cycles can be calculated as

$$
E A C_{o n}\left(T_{o}, T_{n}\right)=\left[P V\left(C_{o, \text { total }}\left(T_{o}\right)\right)+P V\left(C_{n, \text { total }}\left(T_{n}\right)\right) \cdot e^{-r \cdot T_{o}}\right] \cdot \frac{e^{r}-1}{1-e^{-r \cdot\left(T_{o}+T_{n}\right)}} .
$$

The EAC value for two complete utilization cycles of old and new equipment is a function of the two variables $T_{o}$ and $T_{n}$. The values of $T_{o}=T_{o}^{* *}$ and $T_{n}=T_{n}^{* *}$, at which the expression (9) reaches the minimum can be considered optimum service lives of equipment when switching from old equipment to new equipment.

Let us find the $E A C$ value for the second reasoning pattern. Within this pattern, we will analyze the infinite planning horizon. And, during the first full cycle of work, it is planned to use old equipment. Then, during all subsequent cycles of the same duration $T_{n}$, new equipment will be used. In this case, obviously,

$$
\begin{gathered}
E A C_{o n}^{\infty}\left(T_{o}, T_{n}\right)= \\
=\left[P V\left(C_{o, \text { total }}\left(T_{o}\right)\right)+e^{-r \cdot T_{o}} \cdot \sum_{k=0}^{\infty}\left(e^{-r \cdot T_{n} \cdot k} \cdot P V\left(C_{n, \text { total }}\left(T_{n}\right)\right)\right)\right] \cdot\left(e^{r}-1\right)= \\
=\left[P V\left(C_{o, \text { total }}\left(T_{o}\right)\right)+P V\left(C_{n, \text { total }}\left(T_{n}\right)\right) \cdot \frac{e^{-r \cdot T_{o}}}{1-e^{-r \cdot T_{n}}}\right] \cdot\left(e^{r}-1\right)
\end{gathered}
$$

We determine the values of $T_{o}=T_{o}^{* * *}$ and $T_{n}=T_{n}^{* * *}$ at which the expression (10) reaches the minimum. It is easy to check that $T_{n}^{* * *}=T_{n}^{*}$.

Due to the influence of various random factors, as equipment ages, significant fluctuations in the operating costs of equipment are possible. Therefore, it makes sense to describe the dynamics of changes in the rates of the operating costs of equipment using random processes $c_{o}(t, \omega)$ and $c_{n}(t, \omega)$, where $\omega \in \Omega,(\Omega, \mathrm{A}, \mathrm{P})$ is the probability space. Moreover, the mathematical 
expectations of these random processes are $c_{o}(t)=E\left(c_{o}(t, \omega)\right)$ and $c_{n}(t)=E\left(c_{n}(t, \omega)\right)$, respectively. In this case, the current operating costs of equipment will be described by the corresponding random processes

$$
\begin{aligned}
& P V\left(C_{o, \text { oper }}\left(T_{o}, \omega\right)\right)=\int_{0}^{T_{o}} c_{o}(\tau, \omega) \cdot e^{-r \cdot \tau} d \tau, \\
& P V\left(C_{n, \text { oper }}\left(T_{n}, \omega\right)\right)=\int_{0}^{T_{n}} c_{n}(\tau, \omega) \cdot e^{-r \cdot \tau} d \tau .
\end{aligned}
$$

Thus, the $E A C$ value will also be a random variable.

Let us study the influence of the choice of the service life of equipment on the dispersion of values of the random variable $E A C$ for the chain of successively replaced machines of old and new type, namely - on the value of the standard deviation $\sigma\left(E A C_{o n}\left(T_{o}, T_{n}, \omega\right)\right)$. To this end, consider the covariance functions of the random processes $c_{o}(t, \omega)$ and $c_{n}(t, \omega)$, respectively:

$$
\begin{gathered}
K_{o}\left(t_{1}, t_{2}\right)=E\left(\left(c_{o}\left(t_{1}, \omega\right)-c_{o}\left(t_{1}\right)\right)\left(c_{o}\left(t_{2}, \omega\right)-c_{o}\left(t_{2}\right)\right)\right), \\
K_{n}\left(t_{1}, t_{2}\right)=E\left(\left(c_{n}\left(t_{1}, \omega\right)-c_{n}\left(t_{1}\right)\right)\left(c_{n}\left(t_{2}, \omega\right)-c_{n}\left(t_{2}\right)\right)\right) .
\end{gathered}
$$

It is natural to assume that the dynamics of the operating costs of each subsequent machine does not depend on the costs of previous machines. Therefore, using (9) and the properties of covariance functions of random processes, we obtain

$$
\begin{aligned}
& \sigma^{2}\left(E A C_{o n}\left(T_{o}, T_{n}, \omega\right)\right)= \\
& =\left(\frac{e^{r}-1}{1-e^{-r \cdot\left(T_{o}+T_{n}\right)}}\right)^{2} \cdot\left[\sigma^{2}\left(P V\left(C_{o, \text { total }}\left(T_{o}, \omega\right)\right)\right)+e^{-2 \cdot r \cdot T_{o}} \cdot \sigma^{2}\left(P V\left(C_{n, \text { total }}\left(T_{n}, \omega\right)\right)\right)\right]= \\
& =\left(\frac{e^{r}-1}{1-e^{-r \cdot\left(T_{o}+T_{n}\right)}}\right)^{2} \cdot\left[\int_{0}^{T_{0}} \int_{0}^{T_{Q}} K_{o}\left(t_{1}, t_{2}\right) \cdot e^{-r \cdot\left(t_{1}+t_{2}\right)} d t_{1} d t_{2}+\right. \\
& \left.+e^{-2 \cdot r \cdot T_{0}} \cdot \int_{0}^{T_{n}} \int_{0}^{T_{n}} K_{n}\left(t_{1}, t_{2}\right) \cdot e^{-r \cdot\left(t_{1}+t_{2}\right)} d t_{1} d t_{2}\right]
\end{aligned}
$$

Similarly, from (10) for the second reasoning pattern, we obtain 


$$
\begin{gathered}
\sigma^{2}\left(E A C_{o n}^{\infty}\left(T_{o}, T_{n}, \omega\right)\right)= \\
=\left(e^{r}-1\right)^{2} \cdot\left[\sigma^{2}\left(P V\left(C_{o, \text { total }}\left(T_{o}, \omega\right)\right)\right)+e^{-2 \cdot r \cdot T_{o}} \cdot \sigma^{2}\left(\sum_{k=0}^{\infty}\left(e^{-r \cdot T_{n} \cdot k} \cdot P V\left(C_{n, \text { total }}\left(T_{n}, \omega\right)\right)\right)\right)\right]= \\
=\left(e^{r}-1\right)^{2} \cdot\left[\sigma^{2}\left(P V\left(C_{o, \text { total }}\left(T_{o}, \omega\right)\right)\right)+\frac{e^{-2 \cdot r \cdot T_{o}}}{1-e^{-2 \cdot r \cdot T_{n}}} \cdot \sigma^{2}\left(P V\left(C_{n, \text { total }}\left(T_{n}, \omega\right)\right)\right)\right]= \\
=\left(e^{r}-1\right)^{2} \cdot\left[\int_{0}^{T_{o} T_{o}} \int_{0}^{-2 \cdot r \cdot T_{o}} K_{o}\left(t_{1}, t_{2}\right) \cdot e^{-r \cdot\left(t_{1}+t_{2}\right)} d t_{1} d t_{2}+\frac{e^{T_{n}} T_{n}}{1-e^{-2 \cdot r \cdot T_{n}}} \cdot \int_{0}^{\int_{0}} K_{n}\left(t_{1}, t_{2}\right) \cdot e^{-r \cdot\left(t_{1}+t_{2}\right)} d t_{1} d t_{2}\right]
\end{gathered}
$$

In practice, in addition to optimizing the values of equipment performance indicators, the degree of dispersion of values of these indicators is also important. Based on the above methods of estimating the average expected indicators and the level of $E A C$ fluctuations, we can consider the two-criteria minimization problem

$$
\min _{T_{o}, T_{n}}\left(E\left(E A C_{o n}\left(T_{o}, T_{n}, \omega\right)\right), \sigma\left(E A C_{o n}\left(T_{o}, T_{n}, \omega\right)\right)\right)
$$

In (17), the search of equipment replacement terms $T_{o}$ and $T_{n}$ is carried out, at which the minimum values of $E\left(E A C_{o n}\left(T_{o}, T_{n}, \omega\right)\right)$ and $\sigma\left(E A C_{o n}\left(T_{o}, T_{n}, \omega\right)\right)$ are attained. It is similarly possible to investigate the problem

$$
\min _{T_{o}, T_{n}}\left(E\left(E A C_{o n}^{\infty}\left(T_{o}, T_{n}, \omega\right)\right), \sigma\left(E A C_{o n}^{\infty}\left(T_{o}, T_{n}, \omega\right)\right)\right) .
$$

of finding the equipment replacement terms $T_{o}$ and $T_{n}$, at which balanced minimum values of $E\left(E A C_{o n}^{\infty}\left(T_{o}, T_{n}, \omega\right)\right)$ and $\sigma\left(E A C_{o n}^{\infty}\left(T_{o}, T_{n}, \omega\right)\right)$ are achieved.

\section{RESULTS OF THE STUDY OF OPTIMUM TERMS OF EQUIPMENT REPLACEMENT}

We investigate optimum replacement terms for harbor container cranes. The costs of equipment of the old and new type are $A_{o}=240$ thousand USD and $A_{n}=195$ thousand USD, respectively. The average dynamics of operating costs for container cranes is described by the functions $c_{o}(t)=75.07+0.21 \cdot t^{2.11}$, thousand USD/year and $c_{n}(t)=60.52+0.22 \cdot t^{2.52}$, thousand USD/year. These functions were obtained on the basis of the regression analysis of changes in operating costs for a sample of 27 old-type container cranes. Fig. 10 shows the box plot, which presents the dynamics of changes in operating costs of oldtype container cranes according to this sample. In Fig. 11, the solid line shows the curve of changes in average operating costs of old-type container cranes, 
and the dashed lines - the borders of the band, within which, with a 0.9 probability, the values of operating costs are found.

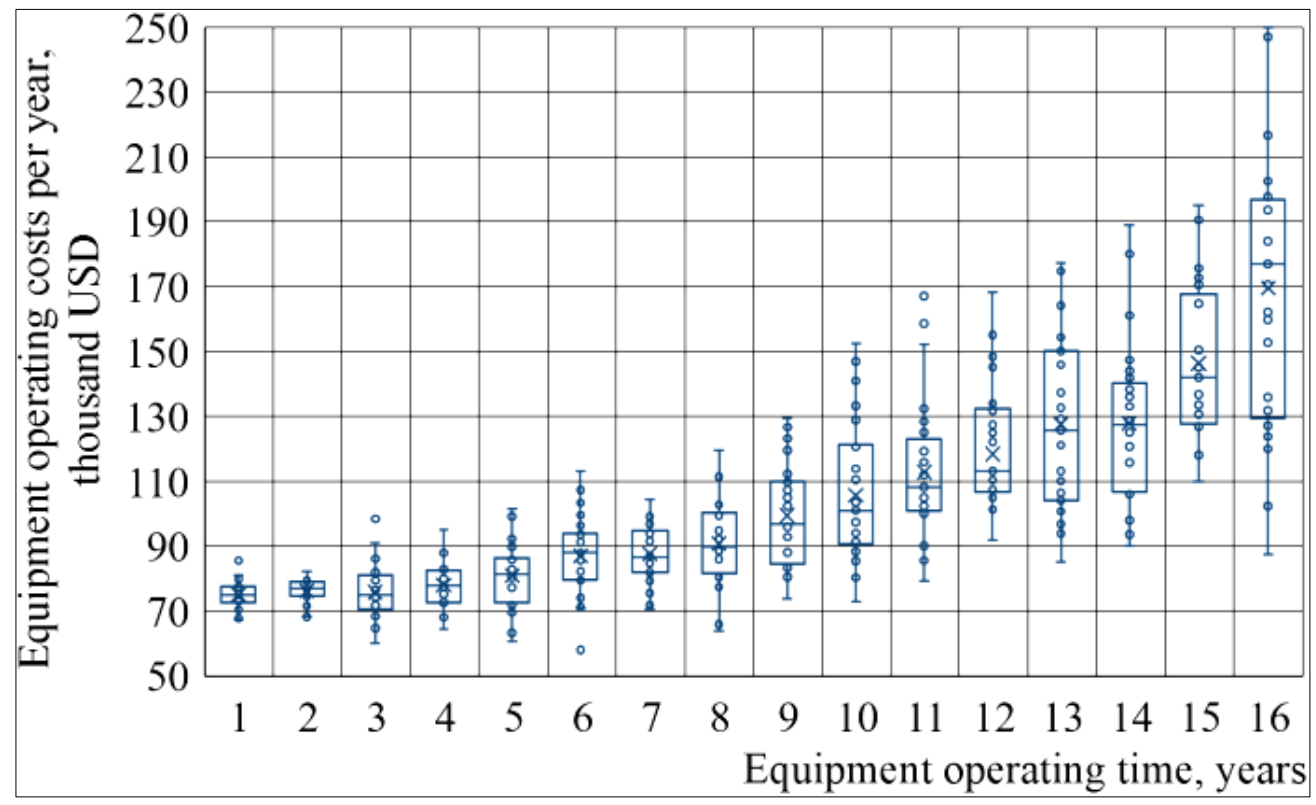

Fig. 10. Statistical data on changes in operating costs of old container cranes

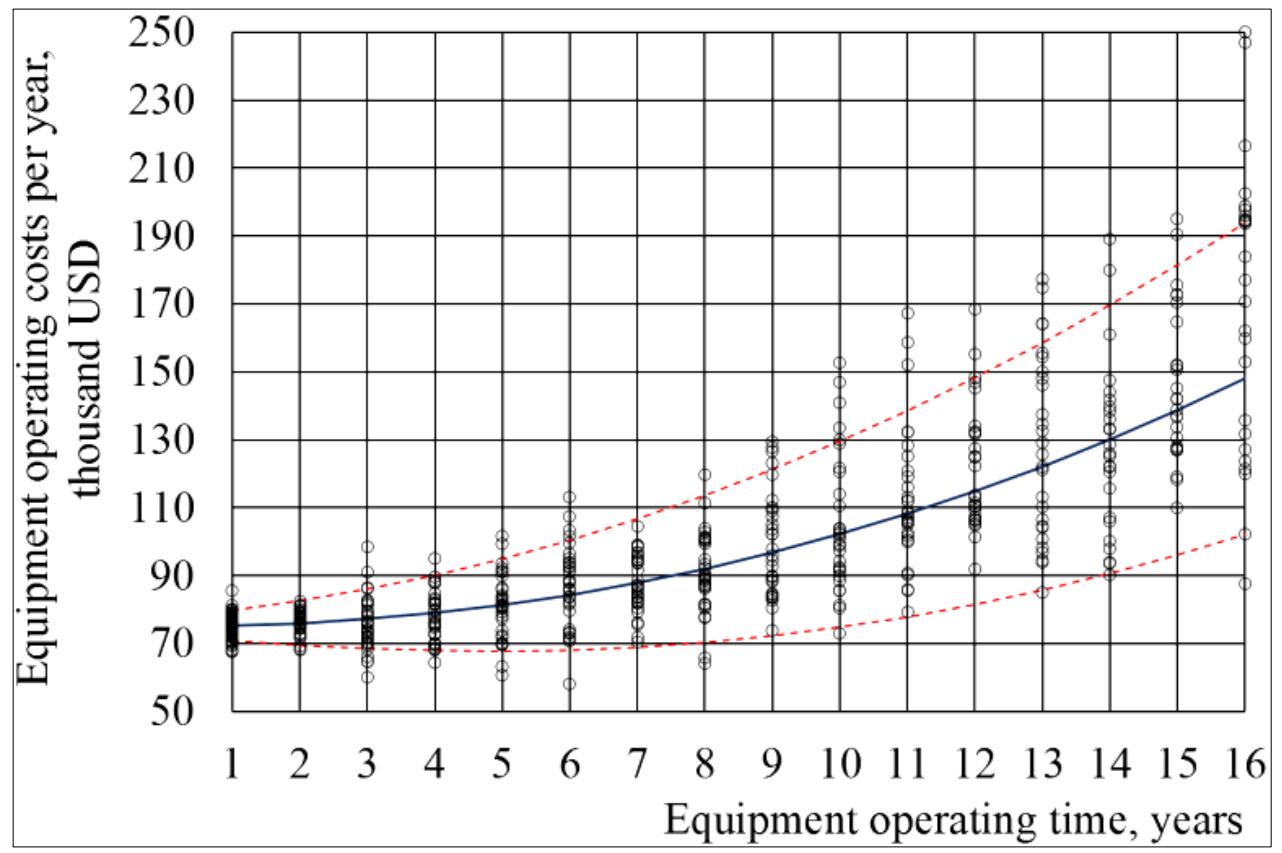

Fig. 11. Changes in operating costs for old container cranes

The cost of dismantling and sale of equipment depending on service life is described by the function $S_{o}(t)=-5.15-140.01 \cdot(1.14 \cdot t+1)^{-1.32}$ thousand USD for old equipment and $S_{n}(t)=-1.50-159.99 \cdot(0.51 \cdot t+1)^{-2.02}$ thousand USD - for new. These functions were also obtained on the basis of the statistical analysis of actual data. The annual interest rate given in shares is assumed to be $r=0.1$. 
All numerical computations by the formulas (1) - (18), necessary for plotting the graphs and finding the optimum values given in the paper, were implemented in the Maple mathematical computing environment. The graphs of changes in the values of $E A C_{o}(T)$ and $E A C_{n}(T)$, calculated by the formulas (1) - (7), are shown in Fig. 12. The expression (6) reaches a minimum with $T_{o}^{*}=12.28$, and the expression $(7)-$ with $T_{n}^{*}=8.05$.

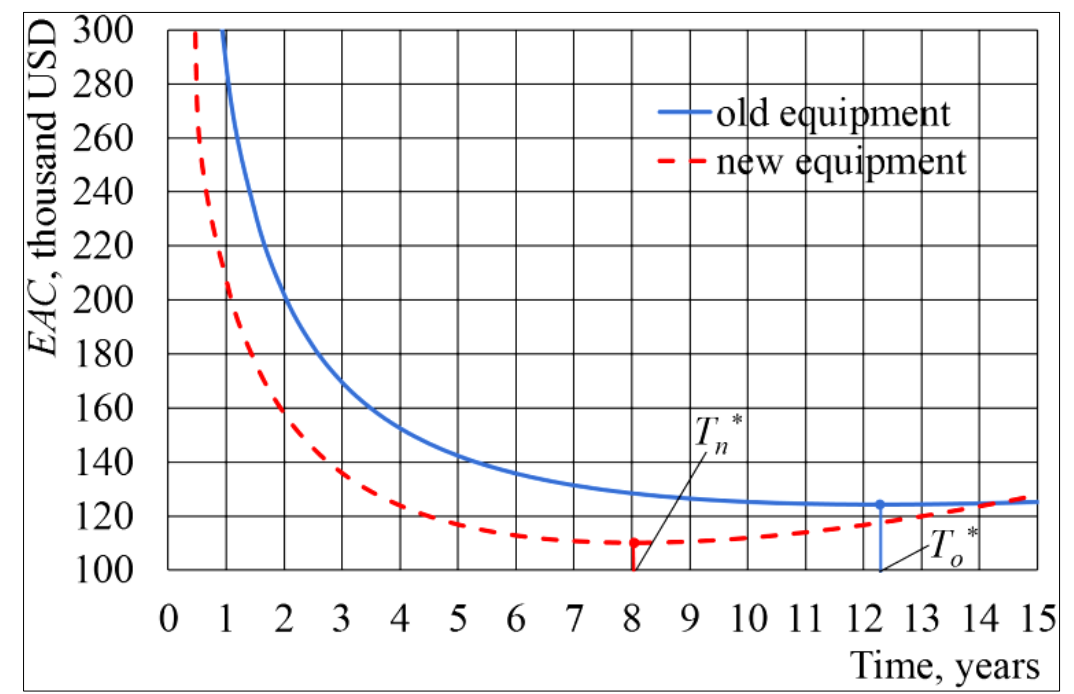

Fig. 12. Graph of $E A C$ change for old and new equipment depending on service life

Fig. 13 and 14 show the surfaces of changes in the EAC values calculated by the formulas (9), (10), with two replacement cycles and with an infinite number of equipment replacement cycles, depending on the time of utilization of old and new equipment.

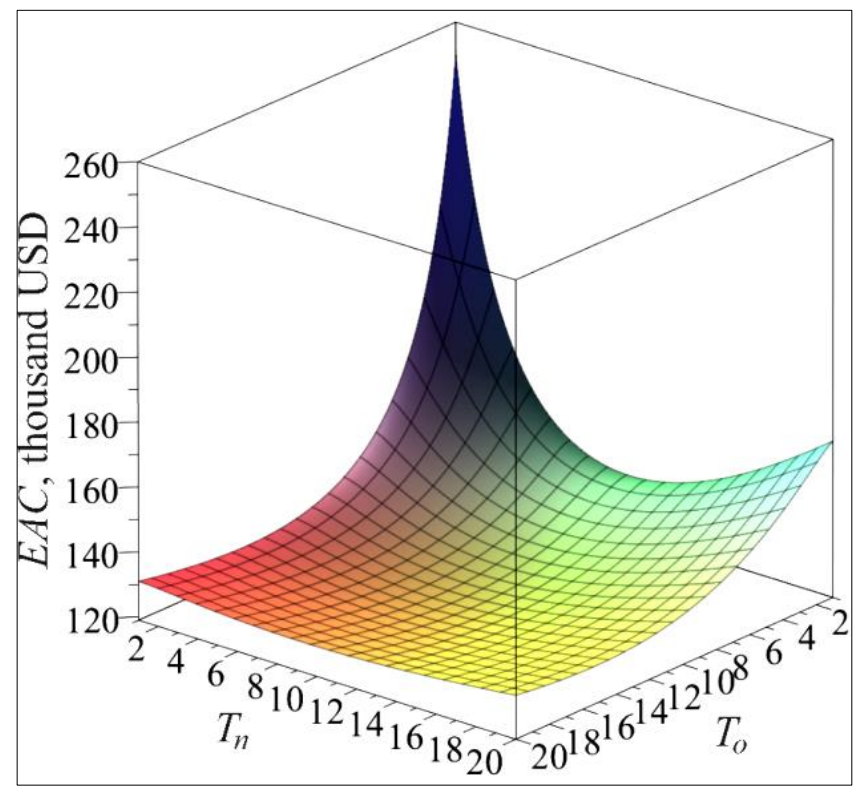

Fig. 13. Changes in the $E A C_{o n}\left(T_{o}, T_{n}\right)$ values with two equipment replacement cycles 


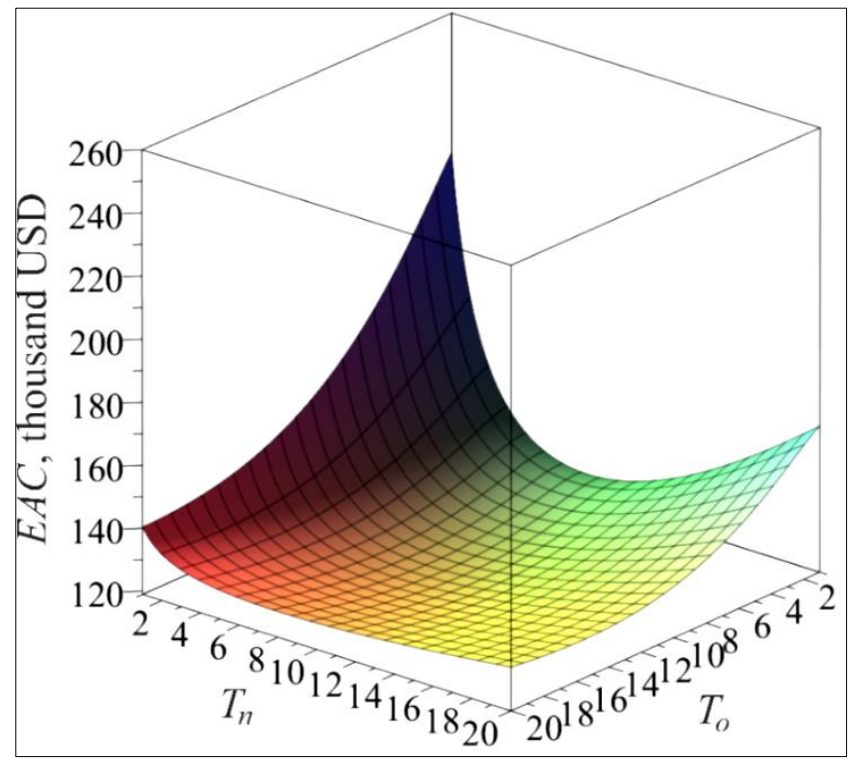

Fig. 14. Changes in the $E A C_{o n}^{\infty}\left(T_{o}, T_{n}\right)$ values with an infinite number of equipment replacement cycles

The minimum value of $E A C_{o n}\left(T_{o}, T_{n}\right)$ is reached with $\left(T_{o}^{* *}, T_{n}^{* *}\right)=(10.93$, 8.83 ) and is 121.29 thousand USD. And the minimum value of $E A C_{o n}^{\infty}\left(T_{o}, T_{n}\right)$ is reached with $\left(T_{o}^{* * * *}, T_{n}^{* * * *}\right)=(10.15,8.05)$ and is 119.60 thousand USD.

Fig. 15 shows the graphs of changes in the $E A C$ values for each individual piece of equipment when replacing old equipment with new equipment. Fig. 16 shows the graphs of $E A C$ changes for each individual piece of equipment with one operation cycle of old equipment and an infinite number of subsequent operation cycles of new equipment. In Fig. 15 and Fig. 16, the blue solid line represents the curve of changes in the $E A C$ values for old equipment, and the red dotted line shows the $E A C$ curves for new equipment.

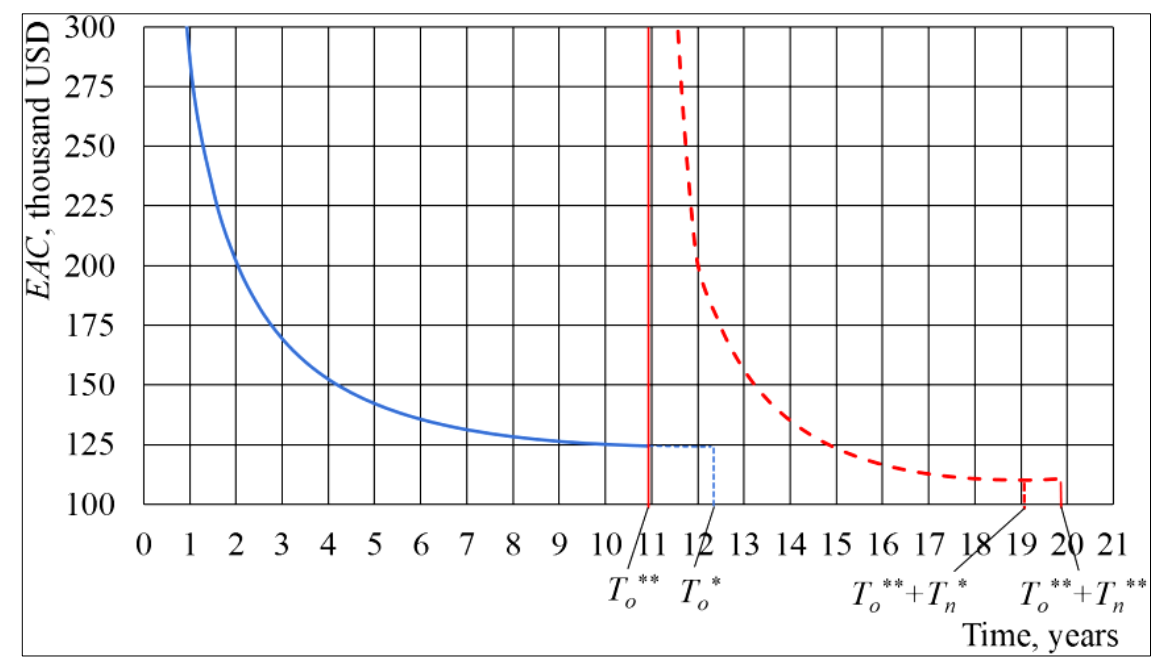

Fig. 15. Graph of $E A C$ change with two equipment replacement cycles 


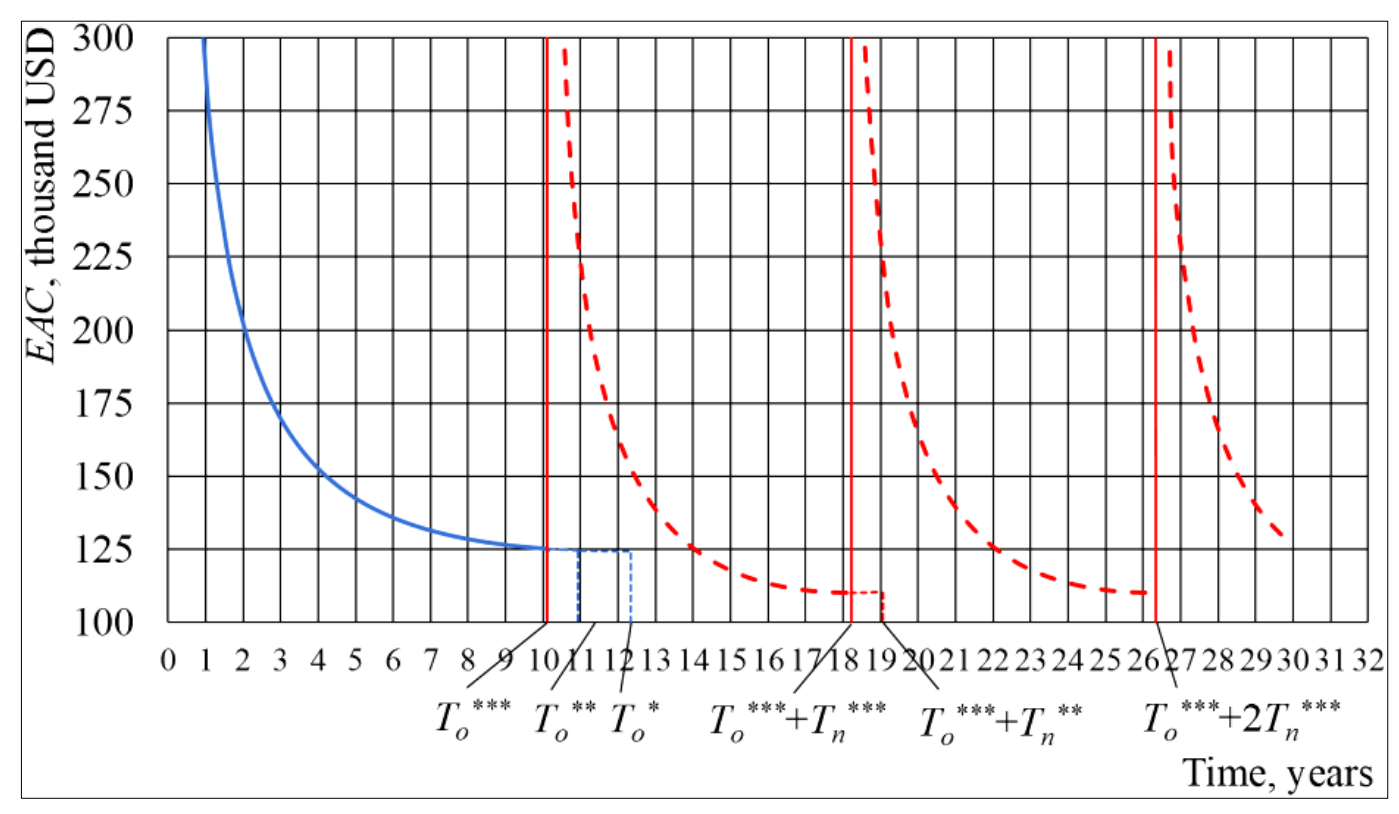

Fig. 16. Graph of $E A C$ change with an infinite number of equipment replacement cycles

Calculations showed that the value of $T_{o}^{*}$ significantly exceeds the value of $T_{o}^{* *}$, and $T_{n}^{* *}$ exceeds $T_{n}^{*}$. It is obvious that the more efficient the new equipment is, the greater the difference between $T_{o}^{*}$ and $T_{o}^{* *}$.

We investigate the degree of dispersion of $E A C$ values depending on the choice of equipment replacement terms with possible random changes in operating costs. Estimation of the operating cost function $c_{o}(t)$ and the covariance function $K_{o}\left(t_{1}, t_{2}\right)$ for old equipment is usually not very difficult, since in most cases there is enough statistical data for old equipment. But for new equipment, there is sometimes not enough information for reliable statistical estimation of equipment utilization under given specific conditions. In this case, the estimate of the dynamics of the average level of operating costs and the covariance function $K_{n}\left(t_{1}, t_{2}\right)$ can be obtained on the basis of technical documentation and expert assessments. Introduction and first experience of using innovative equipment are often associated with increased risks. And this risk should be taken into account when justifying the values of the covariance function $K_{n}\left(t_{1}, t_{2}\right)$.

Further, when describing the covariance functions for old and new equipment, we will use the following expression

$$
K\left(t_{1}, t_{2}\right)=\left(a_{1} \cdot\left(t_{1}+t_{2}\right)^{a_{2}}+a_{3}\right) \cdot \exp \left(\frac{-\left(t_{1}-t_{2}\right)^{2}}{a_{4} \cdot\left(t_{1}+t_{2}\right)^{a_{5}}+a_{6}}\right),
$$

where the set of constant coefficients $a=\left(a_{1} ; \ldots ; a_{6}\right)$ is determined by regression analysis methods, separate for each type of equipment. Such choice of a type 
of covariance function makes it easy to interpret the effect of each of the constant coefficients on the properties of the studied random process of changes in the operating costs of equipment. Thus, the coefficients $a_{1}, a_{2}$ and $a_{3}$ determine the growth rate, the curve shape and the initial value of the dispersion function, respectively, for the random process under study. The coefficients $a_{4}, a_{5}$ and $a_{6}$ reflect the way in which the degree of interrelation between the values of the operating costs of equipment is changed at different timepoints. The use of covariance functions of the type (19) made it possible to describe quite accurately the process of changes in the operating costs for container cranes. However, this form of covariance functions is not universal. The form of the function $K\left(t_{1}, t_{2}\right)$ should be selected and justified individually for different types of equipment and different operating conditions.

For the considered old type container cranes, a set of values of constant coefficients $a_{o}=(0.3501 ; 2.21 ; 35.21 ; 0.002 ; 2.50 ; 15.40)$ in the function (19) was determined based on the regression analysis. Accordingly, for container cranes of new type, the values of coefficients $a_{n}=(0.0075 ; 3.50 ; 105.21 ; 0.015 ; 3.01 ; 5.61)$ were obtained.

Fig. 17, 18 present the graphs of the covariance functions $K_{o}\left(t_{1}, t_{2}\right)$ and $K_{n}\left(t_{1}, t_{2}\right)$ for container cranes of the old and new type determined by the function of the form (19) with the above values of the coefficients. From Fig. 17, 18 it can be seen that dispersion of the operating cost values for new equipment is much higher than for old equipment. Moreover, for new equipment, there is also a greater correlation between the values of operating cost at different timepoints than for old.

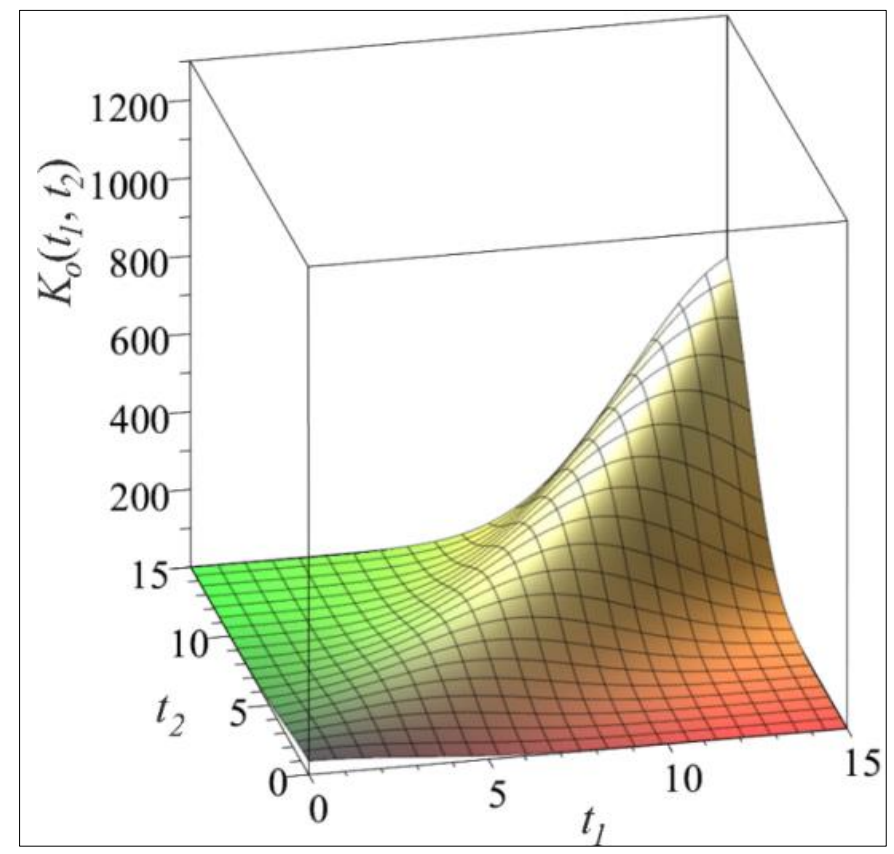

Fig. 17. Graph of the covariance function $K_{o}\left(t_{1}, t_{2}\right)$ 


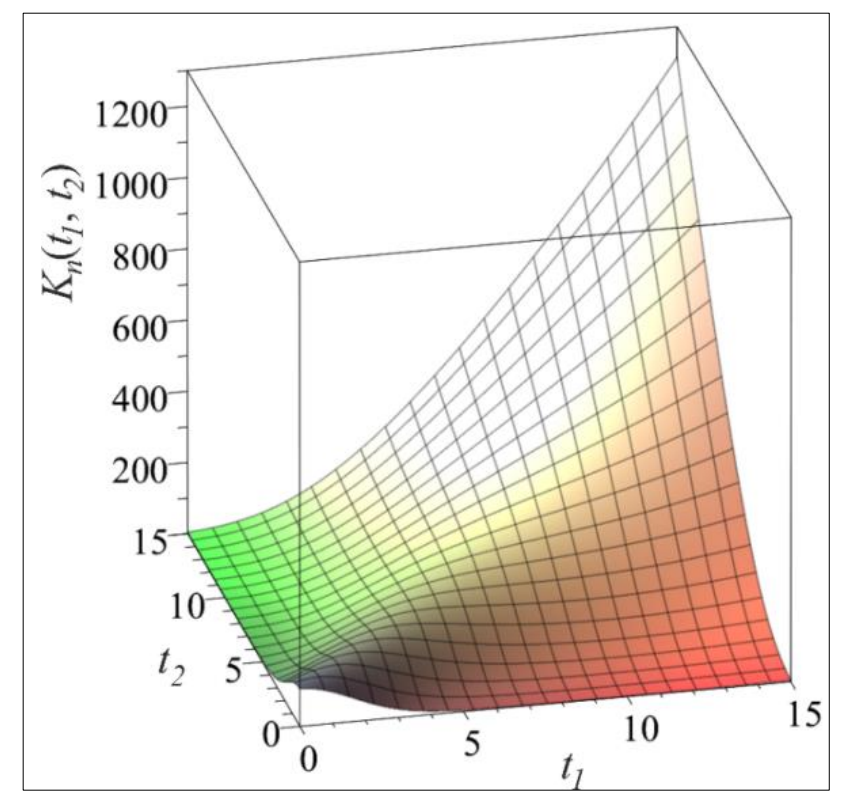

Fig. 18. Graph of the covariance function $K_{n}\left(t_{1}, t_{2}\right)$

Verification of the indicators was carried out on the basis of actual operation data of harbor container cranes. The values of all input data for calculations by the formulas (1)-(18) given in the paper, including statistical estimates of the covariance functions $K_{o}\left(t_{1}, t_{2}\right)$ and $K_{n}\left(t_{1}, t_{2}\right)$ are obtained using the statistical analysis of actual data.

Fig. 19 presents the graph of changes in the standard deviation of the EAC values calculated by the formula (15), depending on equipment replacement terms with two replacement cycles. A similar graph of changes in the standard deviation of the $E A C$ values calculated by the formula (16) with an infinite number of replacement cycles is shown in Fig. 20.

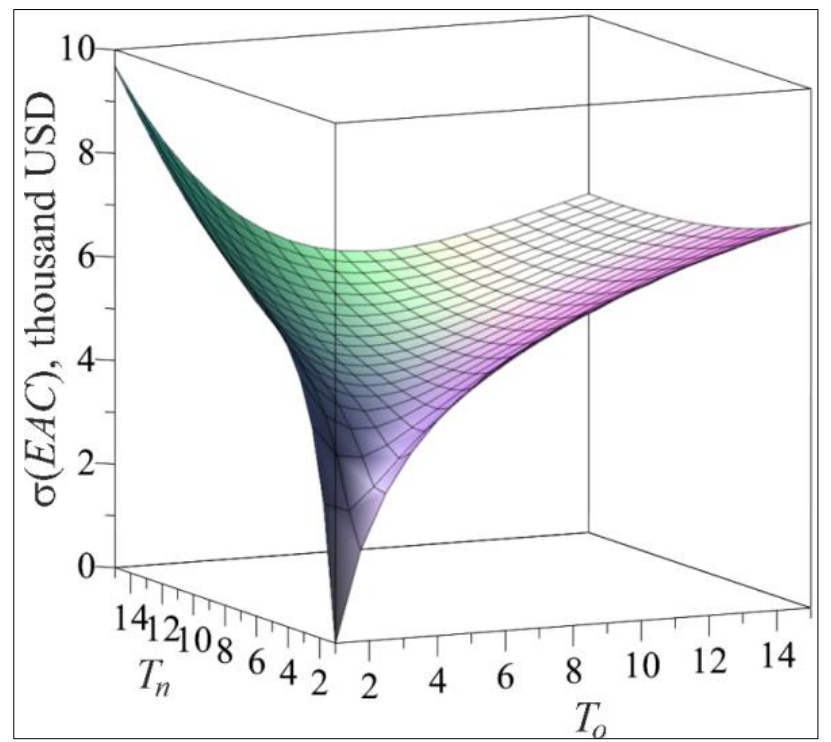

Fig. 19. Graph of the function $\sigma\left(E A C_{o n}\left(T_{o}, T_{n}, \omega\right)\right)$ 


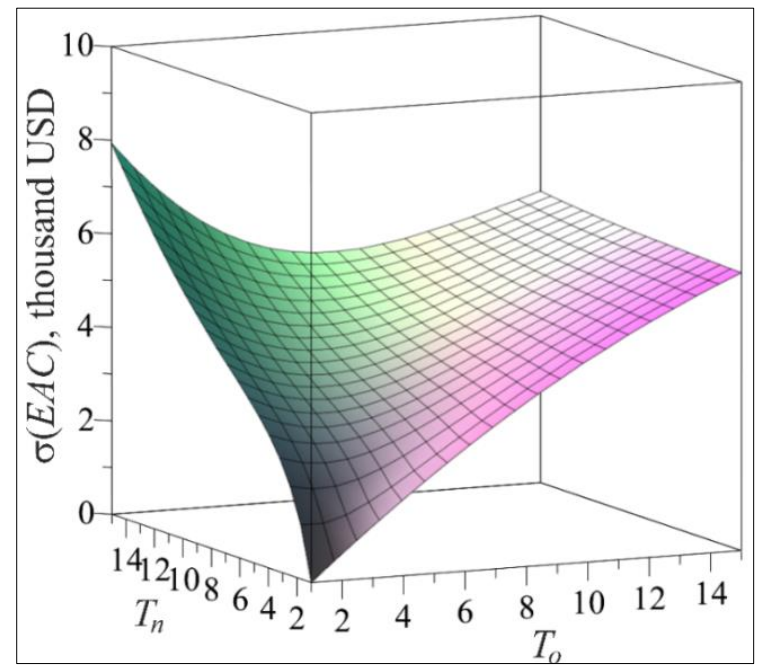

Fig. 20. Graph of the function $\sigma\left(E A C_{o n}^{\infty}\left(T_{o}, T_{n}, \omega\right)\right)$

Comparing Fig. 13, 19, and also Fig. 14, 20, we can see that the values of $T_{o}$ and $T_{n}$, optimum from the point of view of the average $E A C$, will not correspond to the minimum values of standard deviations of $E A C$. Therefore, in order to justify such a choice of equipment replacement terms, at which the balance between the minimum and the dispersion degree of $E A C$ values is achieved, it is necessary to investigate the multi-criteria optimization problems (17) and (18). Let us analyze the relationship between the values of $E\left(E A C_{o n}\left(T_{o}, T_{n}, \omega\right)\right)$ and $\sigma\left(E A C_{o n}\left(T_{o}, T_{n}, \omega\right)\right)$. Fig. 21 shows the set of points, the coordinates of which are respectively equal to $E\left(E A C_{o n}\left(T_{o}, T_{n}, \omega\right)\right)$ and $\sigma\left(E A C_{o n}\left(T_{o}, T_{n}, \omega\right)\right)$ and are determined by the choice of the values of $T_{o}$ and $T_{n}$. The unimprovable points lying on the Pareto frontier of the multi-criteria optimization problem are given in red (17). The coordinates of some unimprovable solutions, as well as the corresponding values of equipment replacement terms $T_{o}$ and $T_{n}$, are shown in Table 1 .

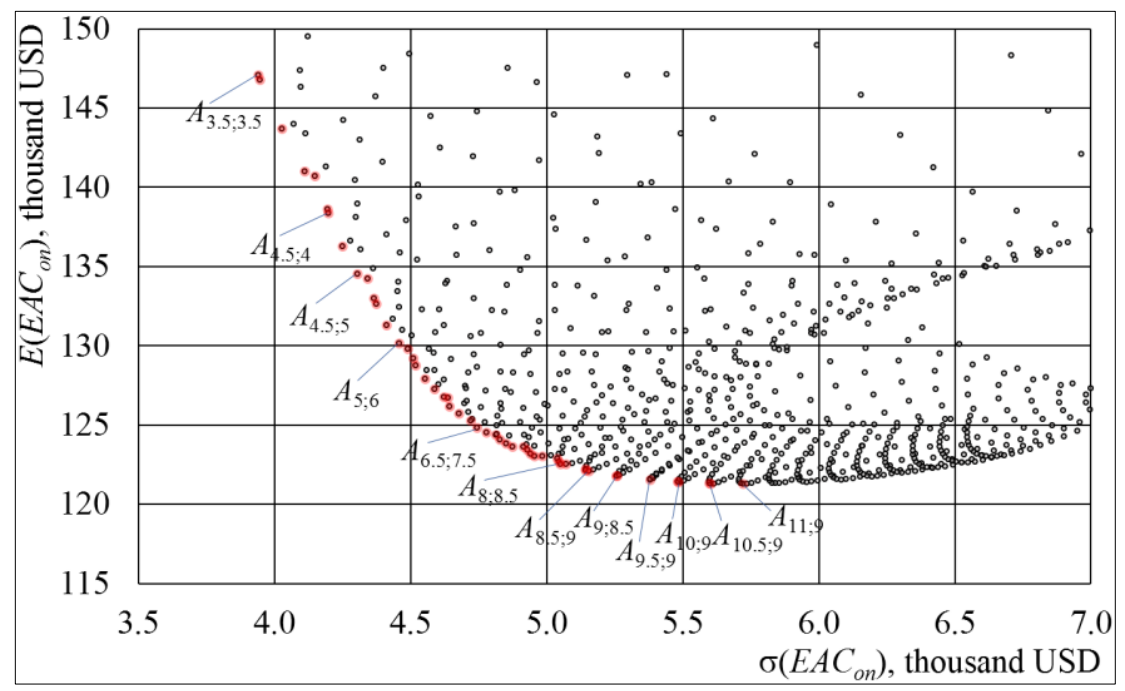

Fig. 21. Relationship between the values of $E\left(E A C_{o n}\left(T_{o}, T_{n}, \omega\right)\right)$ and $\sigma\left(E A C_{o n}\left(T_{o}, T_{n}, \omega\right)\right)$ for different values of $T_{o}$ and $T_{n}$ 


\section{Some unimprovable solutions}

of the two-criteria optimization problem (17)

\begin{tabular}{|c|c|c|}
\hline $\begin{array}{c}\text { Point designation } \\
\text { on the Pareto frontier, } \\
A_{T_{o} ; T_{n}}\end{array}$ & $E\left(E A C_{o n}\left(T_{o}, T_{n}, \omega\right)\right)$ & $\sigma\left(E A C_{o n}\left(T_{o}, T_{n}, \omega\right)\right)$ \\
\hline$A_{3.5 ; 3.5}$ & 147.10 & 3.94 \\
\hline$A_{4.5 ; 4}$ & 138.37 & 4.20 \\
\hline$A_{4.5 ; 5}$ & 134.52 & 4.31 \\
\hline$A_{5 ; 6}$ & 130.16 & 4.46 \\
\hline$A_{6.5 ; 7.5}$ & 124.84 & 4.74 \\
\hline$A_{8 ; 8.5}$ & 122.56 & 5.05 \\
\hline$A_{8.5 ; 9}$ & 122.12 & 5.16 \\
\hline$A_{9 ; 8.5}$ & 121.82 & 5.25 \\
\hline$A_{9.5 ; 9}$ & 121.57 & 5.38 \\
\hline$A_{10 ; 9}$ & 121.40 & 5.48 \\
\hline$A_{10.5 ; 9}$ & 121.31 & 5.60 \\
\hline$A_{11 ; 9}$ & 121.29 & 5.72 \\
\hline
\end{tabular}

The points lying on the Pareto frontier of the multi-criteria optimization problem (18) are given in red in Fig. 22. The coordinates of some of these points are shown in Table 2.

It is obvious that the points that did not fall on the Pareto frontier are of no practical interest. To find the optimum service life of equipment, it is advisable to consider only unimprovable solutions of the problems (17), (18).

This paper does not assume the use of a single integrated criterion for solving the problems (17) and (18). On the contrary, the reduction of the problems (17) and (18) to the study of any integrated indicators or convolutions of criteria would make the analysis of the problem of choosing the optimum equipment replacement terms more formal and would cut off much of the information that could help the DM (decision-maker) to make a more reasonable choice. Not the packing of all indicators into a single integrated indicator, but the construction and analysis of the entire Pareto frontier, makes it possible to analyze the problem as deeply as possible ${ }^{47}$.

47 Podinovskiy V. V., Nogin V. D. (1982) Pareto-optimal'nye resheniya mnogokriterial'nyh zadach [Pareto-optimal solutions to multicriteria problems]. Moscow: Nauka. (in Russian) 


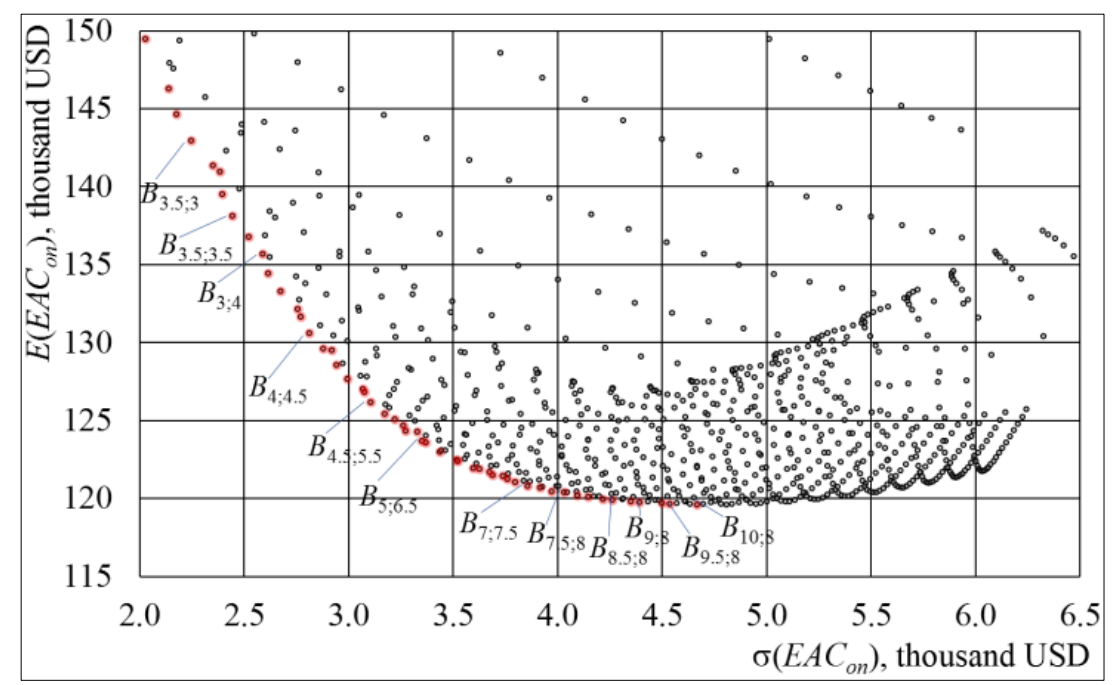

Fig. 22. Relationship between the values of $E\left(E A C_{o n}^{\infty}\left(T_{o}, T_{n}, \omega\right)\right)$ and $\sigma\left(E A C_{o n}^{\infty}\left(T_{o}, T_{n}, \omega\right)\right)$ for different values of $\boldsymbol{T}_{\boldsymbol{o}}$ and $\boldsymbol{T}_{\boldsymbol{n}}$

Table 2

Some unimprovable solutions

of the two-criteria optimization problem (18)

\begin{tabular}{|c|c|c|}
\hline $\begin{array}{c}\text { Point designation on the } \\
\text { Pareto frontier, } B_{T_{o} ; T_{n}}\end{array}$ & $E\left(E A C_{o n}^{\infty}\left(T_{o}, T_{n}, \omega\right)\right)$ & $\sigma\left(E A C_{o n}^{\infty}\left(T_{o}, T_{n}, \omega\right)\right)$ \\
\hline$B_{3 ; 4}$ & 135.69 & 2.59 \\
\hline$B_{3.5 ; 3}$ & 142.98 & 2.25 \\
\hline$B_{3.5 ; 3.5}$ & 138.14 & 2.44 \\
\hline$B_{4 ; 4.5}$ & 130.62 & 2.81 \\
\hline$B_{4.555 .5}$ & 126.19 & 3.11 \\
\hline$B_{5 ; 6.5}$ & 123.61 & 3.37 \\
\hline$B_{7 ; 7.5}$ & 120.82 & 3.86 \\
\hline$B_{7.5 ; 8}$ & 120.40 & 4.03 \\
\hline$B_{8.5 ; 8}$ & 119.90 & 4.26 \\
\hline$B_{9 ; 8}$ & 119.74 & 4.39 \\
\hline$B_{9.5 ; 8}$ & 119.64 & 4.54 \\
\hline$B_{10 ; 8}$ & 119.60 & 4.67 \\
\hline
\end{tabular}

The shape of the surfaces $\sigma\left(E A C_{o n}\left(T_{o}, T_{n}, \omega\right)\right)$ and $\sigma\left(E A C_{o n}^{\infty}\left(T_{o}, T_{n}, \omega\right)\right)$ is due to the influence of several factors. Comparing Fig. 19, 20, it can be seen that the values of standard deviations for the indicator $E A C_{o n}\left(T_{o}, T_{n}, \omega\right)$ are greater than for $E A C_{o n}^{\infty}\left(T_{o}, T_{n}, \omega\right)$. This difference is especially marked in cases when $T_{n}$ significantly exceeds $T_{o}$. This is explained by the effect of overlapping and mutual compensation of random multidirectional fluctuations of independent random variables that make up an infinite sum in the evaluation of $\sigma\left(E A C_{o n}^{\infty}\left(T_{o}, T_{n}, \omega\right)\right)$. Thus, the values of the indicators of chains of 
successively replaced machines on the long planning horizon are more stable. It should also be borne in mind that the level of fluctuations in the operating costs of machines that are the first in the chain of successively replaced equipment have a greater contribution to the values of the indicators $\sigma\left(E A C_{o n}\left(T_{o}, T_{n}, \omega\right)\right)$ and $\sigma\left(E A C_{o n}^{\infty}\left(T_{o}, T_{n}, \omega\right)\right)$ due to discounting.

Comparing the Pareto frontiers presented in Fig. 21, 22 and Table 1, 2, it should be noted that the terms of equipment utilization that correspond to the unimprovable solutions of the multicriteria optimization problem (17) are longer than the terms that correspond to unimprovable solutions of the problem (18).

The studies have shown that the minimum value of $E\left(E A C_{o n}\left(T_{o}, T_{n}, \omega\right)\right)$ equals 121.29 thousand USD and is achieved in the case when the service lives of old and new equipment are respectively 11 and 9 years. In this case, the value of $\sigma\left(E A C_{o n}\left(T_{o}, T_{n}, \omega\right)\right)$ is 5.72 thousand USD. In Fig. 21, this solution corresponds to the point $A_{11 ; 9}$. Let us compare the points $A_{11 ; 9}$. and $A_{9 ; 8.5}$ in Fig. 21 . As can be seen, by reducing the service lives of old and new equipment to 9 and 8.5 years, respectively, it is possible to significantly decrease the value of $\sigma\left(E A C_{o n}\left(T_{o}, T_{n}, \omega\right)\right)$, while slightly worsening $E\left(E A C_{o n}\left(T_{o}, T_{n}, \omega\right)\right)$. A similar effect can be observed in Fig. 22, analyzing the Pareto frontier of solutions of the problem (18).

Since $T_{o}^{* * *}<T_{o}^{* *}<T_{o}^{*}$ and $T_{n}^{* *}>T_{n}^{* * * *}=T_{n}^{*}$ it is necessary to specify in what situations it is expedient to use each of these values. The values $T_{o}^{*}$ and $T_{n}^{*}$ determine the optimum terms of equipment replacement, due only to wear and tear. The optimum terms of equipment replacement, taking into consideration both wear and tear and obsolescence, are determined by the values $T_{o}^{* *}, T_{n}^{* *}, T_{o}^{* * *}$ and $T_{n}^{* * *}$. In this case, if accounting of risks is not in question, the choice of the values $T_{o}^{* * * *}$ and $T_{n}^{* * * *}$ as optimum service lives of equipment can be considered the most reasonable, since the maximum planning horizon is taken into account. However, on the maximum planning horizon, estimates of equipment performance fluctuations may be blurred and significantly underestimated. Therefore, when studying the dispersion degree of the values of equipment performance indicators, it may be more appropriate in some cases to consider the planning horizon consisting of two equipment replacement cycles.

\section{CONCLUSIONS}

When modeling transport systems, the accuracy of traffic schedules, precise description of all technological operations associated with service and cargo handling operations are of great importance. However, no less important, and in some cases a much more complex aspect, is the simulation of traffic control services. The traffic control service is engaged in the optimization of the vehicle movement, coordination of various processes going in parallel, as well as the 
operational redistribution of available resources. Modern traffic control services are quite complex man-machine systems. The performance and stability of most transport systems significantly depends on the performance of these services. Therefore, modeling the work of traffic control services is an important and, as a rule, the most time-consuming part of creating simulation models. The simulation model allows to obtain accurate estimations of the key performance indicators and evaluate sustainability of complex transport systems, which in turn allow to justify necessity of additional equipment or resources, to obtain estimates of the system throughput, to justify the tariffs, as well as to simulate the development of possible crisis situations and explore a number of other issues. Despite the complexity of the simulation models design, difficulties in collecting and analyzing input and output data, the practicability of using such an approach in many cases is due to its high efficiency and accuracy.

Based on the estimation of the dispersion of the $E A C$ values, the technique for planning the sea port equipment replacement terms was proposed. This technique allows to justify the terms of replacement of old equipment with new equipment, taking into account both the average expected $E A C$ indicators and the level of possible $E A C$ fluctuations. The studies have shown that due to the choice of equipment renewal terms, dispersion of the $E A C$ values can be significantly reduced, slightly sacrificing the average expected value. Thus, the optimum (from the point of view of the minimum of average values and dispersion degree of $E A C$ ) replacement terms of equipment subject to wear and tear and obsolescence with new equipment were justified.

\section{SUMMARY}

Planning and optimizing of sea port transport infrastructure is an important and often very difficult task. The practical problems, which arose during implementation of the project of justification of the optimum modernization plan for the Emden Ro-Ro terminal were investigated. The simulation model allowed to obtain accurate estimations of the key performance indicators and evaluate sustainability of Emden Ro-Ro terminal transport systems, which in turn allowed to justify necessity of additional equipment or resources, to obtain estimates of the system throughput, as well as to simulate the passing of possible crisis situations and explore a number of other issues.

The optimum terms of replacement of see port equipment subject to wear and tear and obsolescence with more advanced equipment with similar performance were investigated. To this end, the methodology of multi-criteria evaluation of equipment performance indicators when switching to a new type of equipment was proposed. Estimates of the dispersion degree of EAC (Equivalent Annual Cost) values depending on the service life of old and new equipment under conditions when the dynamics of operating costs is subject to random fluctuations were obtained. As a result of the research, the technique for planning the equipment replacement terms was developed. The proposed methodology allows 
justifying the terms of replacement of old equipment with new equipment, taking into account both the average expected EAC values and their level of fluctuations. The studies have shown that due to choosing the equipment renewal terms, it is possible to significantly reduce the degree of dispersion of sea port equipment performance indicators, slightly sacrificing the expected average value.

\section{REFERENCES}

1. Rodrigue J. P., Notteboom T. (2009) The terminalization of supply chains: reassessing the role of terminals in port/hinterland logistical relationships. Maritime Policy \& Management, vol. 36, no. 2, pp. 165-183. DOI 10.1080/03088830902861086

2. Felício J. A., Caldeirinha V., Dionísio A. (2015) The effect of port and container terminal characteristics on terminal performance. Maritime Economics \& Logistics, vol. 17(4), pp. 493-514. DOI 10.1057/mel.2014.33

3. Postan M., Kushnir L. (2016) A method of determination of port terminal capacity under irregular cargo delivery and pickup. Eastern-European Journal of Enterprise Technologies, vol. 4, no. 3(82), pp. 30-37. DOI 10.15587/1729-4061.2016.76285

4. Malaksiano N. A. (2012) On the stability of economic indicators of complex port equipment usage. Actual Problems of Economics, vol. 12, pp. 226-233.

5. Hu Q., Wiegmans B., Corman F., Lodewijks G. (2019) Integration of inter-terminal transport and hinterland rail transport. Flexible Services and Manufacturing Journal, vol. 31(3), pp. 807-831. DOI 10.1007/s10696-01909345-8

6. Panchenko S., Butko T., Prokhorchenko A., Parkhomenko L., Zhurba O. (2018) Development of rational rail network topology for highspeed and conventional trains based on bacterial foraging optimization. International Journal of Engineering \& Technology, vol. 7(4.3), pp. 217-221. DOI dx.doi.org/10.14419/ijet.v7i4.3.19790

7. Lomotko D. V., Alyoshinsky E. S., Zambrybor G. G. (2016) Methodological Aspect of the Logistics Technologies Formation in Reforming Processes on the Railways. Transportation Research Procedia, vol. 14, pp. 2762-2766. DOI 10.1016/j.trpro.2016.05.482

8. Lapkina I., Malaksiano M., Glavatskih V. (2019) To the issue of the possibility of operating vessels at slow speeds. Scientific notes of Taurida National V.I. Vernadsky University. Series: Technical Sciences, vol. 30(69), no. 4, part 2, pp. 134-140. DOI 10.32838/2663-5941/2019.4-2/22

9. Lapkina I. A., Malaksiano N. A. (2019) Mnogokriterial'nyy podkhod k obosnovaniyu vybora proekta priobreteniya i ekspluatatsii sudna-balkera [A multi-criteria approach to justifying the choice of a project of bulk carrier vessel acquiring and operating]. Transport Systems and Technologies: Collection 
of scientific works of the State University of Infrastructure and Technologies, vol. 2, no. 33, pp. 99-110. DOI 10.32703/2617-9040-2019-33-2-10

10. Lapkina I. O., Malaksiano M. O. (2019) O vybore sudna s uchetom izmeneniy kon"yunktury frakhtovogo rynka i tseny na toplivo [On the choice of vessel, taking into account changes in the freight market and fuel prices]. Herald of the Odessa National Maritime university: Collection of Scientific Papers, issue 1 (58), pp. 184-198.

11. Malaksiano M., Melnyk O. (2020) Vessel selection prospects and suitability assessment for oversized cargo transportation. Scientific notes of Taurida National V.I. Vernadsky University. Series: Technical Sciences, vol. 31(70), no. 1, part 2, pp. 135-140. DOI 10.32838/2663-5941/2020.1-2/25

12. Malaksiano M. O., Melnyk O. M. (2020) Obghruntuvannja vyboru sudna dlja frakhtuvannja na umovakh tajm-charteru vrakhovujuchy mozhlyvistj jogho vykorystannja dlja perevezenj neghabarytnykh vantazhiv [Vessel choice justification for chartering on a time-charter basis, considering feasibility for oversized cargo shipment]. Visnyk of Vinnytsia Polytechnical Institute, no. 1, pp. 90-96. DOI 10.31649/1997-9266-2020-148-1-90-96

13. Akimova O. V., Melnyk O. M. (2018) Организационные аспекты перевозки проектных грузов [Organizational aspects of the project cargo transportation]. Herald of the Odessa National Maritime university: Collection of Scientific Papers, issue 3 (56), pp. 123-134.

14. Melnyk O. (2019) Oghljad stanu doslidzhenj problemy perevezenj neghabarytnykh vantazhiv $\mathrm{v}$ Ukrajini [Overview of research status of the problem of transportation of oversized cargoes in Ukraine], Transport Systems and Technologies: Collection of scientific works of the State University of Infrastructure and Technologies, issue 34, pp. 242-253. DOI 10.32703/26179040-2019-34-2-7

15. Melnyk O. (2019) Problems statement and prospects for the development of oversized cargoes transportation in Ukraine. Shipping \& Navigation, issue 29, pp. 142 -153. DOI 10.31653/2306-5761.29.219.142-153

16. O. Melnyk (2019) Pytannja zabezpechennja bezpeky procesu morsjkogho perevezennja neghabarytnykh vantazhiv [Safety issues of oversized cargoes transportation by sea]. Municipal Economy of Cities, vol. 6, no. 152, pp. 204-208. DOI 10.33042/2522-1809-2019-6-152-204-208

17. Hadjiconstantinou E., Ma N. L. (2009) Evaluating straddle carrier deployment policies: a simulation study for the Piraeus container terminal. Maritime Policy \& Management, vol. 36(4), pp. 353-366. DOI 10.1080/03088830903056991

18. Lapkina I. O., Malaksiano M. O., Savchenko Y. S. (2018) Proektuvannja ta optymizacija transportnykh system $\mathrm{Z}$ vykorystannjam metodiv imitacijnogho modeljuvannja [Design and optimization of transport systems by means of simulation modeling]. Herald of the Odessa National Maritime university: Collection of Scientific Papers, issue 3 (56), pp. 80-91. 
19. Lapkina I., Malaksiano M., Savchenko Y. (2020) Design and optimization of maritime transport infrastructure projects based on simulation modeling. Proceedings of the 1st International Workshop IT Project Management (Ukraine, Slavsko, February 18-20, 2020), Slavsko: ITPM 2020, pp. 36-45.

20. Lapkina I. O., Malaksiano M. O. (2016) Modelling and optimization of perishable cargo delivery system through Odesa port. Actual Problems of Economics, issue 3, pp. 353-365.

21. Cimpeanu R., Devine M. T., O’Brien C. (2017) A simulation model for the management and expansion of extended port terminal operations. Transportation Research Part E: Logistics and Transportation Review, vol. 98, pp. 105-131. DOI 10.1016/j.tre.2016.12.005

22. Baldassarra A., Impastato S., Ricci S. (2010) Intermodal terminals simulation for operation management. European Transport, Institute for the Study of Transport within the European Economic Integration, vol. 46, pp. 86-99.

23. Emder Hafen Luftaufnahmen Luftbild Emden-2329. URL: https://schiffe-emden.de/fotostrecke-der-emder-hafen-von-oben/emder-hafenluftaufnahmen-luftbild-emden-2329/ (accessed 2019/11/20).

24. Volkswagen exports at German port. URL: http://www.abc.net.au/ news/2018-06-23/volkswagen-exports-at-german-port/9902388 (accessed 2019/11/20).

25. Google Maps. URL: https://www.google.com/maps/@53.3932007,6. 754134,11z?hl=en\&authuser=0 (accessed 2019/11/20).

26. Port of Emden. URL: http://www.seaports.de/virthos.php?en//HOME/ HAFENSTANDORTE/Emden (accessed 2019/11/20).

27. Adkins R., Paxson D. (2017) Replacement decisions with multiple stochastic values and depreciation. European Journal of Operational Research, vol. 257, no. 1, pp. 174-184. DOI 10.1016/j.ejor.2016.07.006

28. Lapkina I., Malaksiano M. (2018) Estimation of fluctuations in the performance indicators of equipment that operates under conditions of unstable loading. Eastern-European Journal of Enterprise Technologies, vol. 1, no. 3 (91), pp. 22-29. DOI 10.15587/1729-4061.2018.123367

29. Malaksiano N. A. (2013) Ispol'zovanie mnogokriterial'nykh otsenok dlya umen'sheniya riskov pri planirovanii remontov i zamen slozhnogo portovogo oborudovaniya, funktsioniruyushchego $\mathrm{v}$ usloviyakh nepolnost'yu opredelennogo gruzopotoka [The use of multicriteria assessments to reduce risks when planning repairs and replacements of complex port equipment operating in conditions of incompletely defined cargo flow]. Methods and Tools for Managing the Development of Transport Systems: Collection of Scientific Papers Odessa National Maritime University, no. 1(20), pp. 7-27.

30. Malaksiano M. O. (2012) On the optimal repairs and retirement terms planning for complex port equipment when forecast level of employment is uncertain. Economic Cybernetics, issue 4-6 (76-78), pp. 49-56. 
31. Malaksiano M. O. (2013) Vybir strateghiji remontiv i zamin skladnogho obladnannja, shho funkcionuje v umovakh nepostijnoji zajnjatosti [Choosing a strategy for repairs and replacements of complex equipment that operates under condition of unstable employment]. Herald of Khmelnytskyi National University. Economic sciences, issue 1, pp. 215-221.

32. Malaksiano N. A. (2012) O vliyanii urovnya zanyatosti portovogo oborudovaniya na dinamiku ego iznosa [On the influence of the level of employment of port equipment on the dynamics of its depreciation]. Methods and Tools for Managing the Development of Transport Systems: Collection of Scientific Papers Odessa National Maritime University, no. 19, pp. 7-19.

33. Lapkina I. O., Malaksiano M. O. (2018) Opredelenie srokov zameny oborudovaniya $\mathrm{s}$ uchetom iznosa i izmeneniy ego rynochnoy stoimosti [Determination of replacement terms of equipment taking into account deterioration and changes of its market value]. Herald of the Odessa National Maritime university: Collection of Scientific Papers, issue 4 (57), pp. 188-201.

34. Lapkina I.O., Malaksiano M.O. (2018) O povyshenii ustoychivosti pokazateley effektivnosti pri planirovanii srokov obnovleniya slozhnogo oborudovaniya [On improving the sustainability of indicators of effectiveness at the planning of the update of completing equipment updates]. Herald of the Odessa National Maritime university: Collection of Scientific Papers, issue 1 (54), pp. 207-217.

35. Malaksiano M. O. (2012) Ob optimal'nykh srokakh remontov slozhnogo portovogo oborudovaniya [On the optimal timing of repairs of complex port equipment]. Herald of the Dnepropetrovsk National University. Series Economics, issue 6 (3), pp. 186-195.

36. Stutzman S., Weiland B., Preckel P., Wetzstein M. (2017) Optimal replacement policies for an uncertain rejuvenated asset. International Journal of Production Economics, vol. 185, pp. 21-33. DOI 10.1016/j.ijpe.2016.12.018

37. Zambujal-Oliveira J., Duque J. (2011) Operational asset replacement strategy: A real options approach. European Journal of Operational Research, vol. 210, issue 2, pp. 318-325. DOI 10.1016/j.ejor.2010.09.011

38. Liu B., Wu J., Xie M. (2015) Cost analysis for multi-component system with failure interaction under renewing free-replacement warranty. European Journal of Operational Research, vol. 243, issue 3, pp. 874-882. DOI 10.1016/j.ejor.2015.01.030

39. Lapkina I. O., Malaksiano M. O., Malaksiano M. O. (2016) Optimization of the structure of sea port equipment fleet under unbalanced load. Actual Problems of Economics, issue 9, pp. 364-371.

40. Hagspiel V., Huisman K. J. M., Nunes C. (2015) Optimal technology adoption when the arrival rate of new technologies changes. European Journal of Operational Research, vol. 243, issue 3, pp. 897-911. DOI 10.1016/j.ejor.2014.12.024 
41. Adkins R., Paxson D. (2013) Deterministic models for premature and postponed replacement. Omega, vol. 41, issue 6, pp. 1008-1019. DOI 10.1016/j.omega.2013.01.002

42. Chronopoulos M., Siddiqui A. (2014) When is it Better to Wait for a New Version? Optimal Replacement of an Emerging Technology under Uncertainty. Norwegian School of Economics, Department of Business and Management Science, URL: https://brage.bibsys.no/xmlui/bitstream/ handle/11250/217638/1/DiscussionPaper.pdf (accessed 2019/11/20).

43. Nguyen T. P. K., Yeung T. G., Castanier B. (2013) Optimal maintenance and replacement decisions under technological change with consideration of spare parts inventories. International Journal of Production Economics, vol. 143, issue 2, pp. 472-477. DOI 10.1016/j.ijpe.2012.12.003

44. Lapkina I., Malaksiano M. (2018) Elaboration of the equipment replacement terms taking into account wear and tear and obsolescence. Eastern-European Journal of Enterprise Technologies, vol. 3, no. 3 (93), pp. 30-39. DOI 10.15587/1729-4061.2018.133690

45. Jones T. W., Smith D. (1982) An historical perspective of net present value and equivalent annual cost. Accounting Historians Journal, vol. 9, no. 1, pp. 103-110. DOI 10.2308/0148-4184.9.1.103

46. Anderson B. D. O., Bitmead R. R., Johnson C. R., Kokotovic Jr., P. Y., Kosut R. L., Mareels I. M. V., Praly L., Riedle B. D. (1986) Stability of adaptive systems: passivity and averaging analysis. MIT Press.

47. Podinovskiy V. V., Nogin V. D. (1982) Pareto-optimal'nye resheniya mnogokriterial'nyh zadach [Pareto-optimal solutions to multicriteria problems]. Moscow: Nauka. (in Russian)

Information about the authors: Lapkina I. O.,

Professor, Doctor of Economic Sciences, Head of the Department of Management of Logistics Systems and Projects, Odessa National Maritime University 34, Mechnikov str., Odessa, 65029, Ukraine ORCID ID: orcid.org/0000-0001-7468-8993

Malaksiano M. O., Associate Professor, $\mathrm{PhD}$ in Mathematics, Head of the Department of Technical Cybernetics and Information Technology R.V. Merkta,

Odessa National Maritime University 34, Mechnikov str., Odessa, 65029, Ukraine ORCID ID: orcid.org/0000-0002-4075-5112 